\title{
1 A Chinese Language
}

\section{Fangyan before the Twentieth Century}

That there exists a problem with the Chinese language hardly needs to be justified.

Yuen Ren Chao, "The Problem of the Chinese Language"

\section{Introduction}

Elites at the end of the Qing dynasty saw the Chinese language as a problem. A sequence of military defeats beginning with the First Opium War in 1842 made many of them question where their empire had gone wrong. They began with the obvious suspects. They noted that their empire's military technology lagged behind that of their foes, and that its soldiers lacked the training and discipline necessary for modern warfare. But nearly half a century of wars had left the Qing beleaguered, forcing many elites to wonder if their problem was much more foundational - that their weakness lay not in something concrete like infrastructure, but rather, the country's very cultural anatomy, of which language was a central part. When it came to language, these men discussed a myriad of defects, articulated in a myriad of terms. Their written style was outdated, they cried, leading to backward thinking; oral languages were fractured, they moaned, hindering communication. By the dawn of the twentieth century, the only consensus they had reached was that the linguistic landscape they saw before them was fundamentally flawed.

The problem was difficult to define, in part, because the object of their fixation was itself enigmatic. The idea of a "Chinese language" - a language unified in its sound and script used by and representative of a "Chinese nation" - was a foreign concept to Qing elites in the nineteenth century. The impact of the Opium Wars throughout the Qing empire was slow to be felt, but among its earliest consequences was the introduction of new frameworks for imagining a new world order and the Qing's place within it. The wars and their treaties granted Western missionaries, scholars, and diplomats unfettered access to the Qing heartland, and once there, these foreign observers produced a wealth of literature about what they saw. In their writings and 
descriptions, they filtered their narratives through their own histories, deeming the Qing a nation-state called China. With such a designation, the absence of a "Chinese" language to represent it felt palpable.

Perhaps because Western imperialism introduced the dream of a nationstate and a language to match it, histories have tended to emphasize, even overemphasize, how the West galvanized a transformation of the Chinese language. John DeFrancis, for instance, tellingly titled his first chapter of Nationalism and Language Reform in China "The West Shows the Way," arguing that it was European missionaries who taught Qing elites how to change their language and even provided the model to do so. Certainly, it is difficult to ignore the influence of missionaries and diplomats on late-Qing efforts at language reform - from proposals for an alphabetic script to excoriations of classical references in written prose, many of those interested in language reform were borrowing their framework from either the West or Japan. Indeed, language reform and nation building in the late Qing made little sense without understanding the Western texts upon which Qing elites drew. In the words of Haun Saussy, these "cultural bilinguals affect[ed] the societies whose periscopes they [were]."1

But to argue that anyone showed Qing elites "the way" erases how they imagined their own past and present. Scholarship on the nature of the Chinese script and its oral counterparts dates back millennia. And while their significance changed over time, texts from as early as the Han dynasty remained foundational for linguistic study through the early twentieth century. As late-Qing reformers began to imagine a new nationstate and a language to match it, they looked to their own indigenous histories for a Chinese past that could be reinvented to serve its present.

The purpose of this chapter is to introduce the pre-twentieth-century narratives, epistemological frameworks, and cultural meanings that provided a foundation for the invention and simultaneous twinning of a Chinese language and a Chinese nation in the final decades of the Qing. In particular, it examines how Qing scholars and Western sojourners looked specifically at the vernacular languages spoken in the Han heartland of Qing China. I first trace the significance of oral languages as they emerged in written sources before the nineteenth century, with particular emphasis on how evidentiary scholarship in the eighteenth century privileged phonological research in making sense of ancient texts. The chapter subsequently examines the work of Protestant missionaries who, granted access to China's interiors through Britain's victory in the Opium Wars, studied China's local languages in order to proselytize to

${ }^{1}$ Haun Saussy, Great Walls of Discourse and Other Adventures in Cultural China (Cambridge, MA: Harvard University Press, 2001), 13. 
non-elites. A small but influential group of innovative philologists had established a firm precedent for centering philosophical and linguistic research on phonology, thus introducing a detailed methodology for tracing oral languages back in time - components of which are still influential today. Missionaries, on the other hand, simultaneously highlighted the lack of a Chinese standardized national language comparable to those around the world, and made dialects a central point of access of finding or inventing one. The eighteenth-century Qing methods for diachronically studying oral language, given new purpose by the prescriptions of Western sojourners, served as inspiration for nation-building projects initiated at the dawn of the twentieth century.

\section{Seen and Unseen: Language in Qing China}

Interest in the oral origins of the Chinese script has deep historical roots. Chinese philology, called xiaoxue (小學), originated in the Han dynasty (206 BCE-220 CE). A dynasty that legitimized its rule by claiming connections with the past, Han scholars were driven by a desire to, as Michael Lackner writes, "bridge the linguistic gap that separated them from the language of the canonical texts" that were written several hundred years prior. ${ }^{2}$ These Han dynasty scholars produced several "word philologies" to record, compare, and dissect the texts of Chinese antiquity. ${ }^{3}$ This included dictionaries such as Yang Xiong's firstcentury Fangyan (方言), the first recorded study of regional language, and Xu Shen's Shuowen jiezi. ${ }^{4}$

The Shuowen jiezi provided scholars a systematic way to philologically analyze the meaning of individual characters in the philosophical canon a character that was a "loan graph" had different interpretive possibilities

${ }^{2}$ Michael Lackner, "Reconciling the Classics: Two Case Studies from the Song-Yuan Exegetical Approaches," in Sheldon Pollack, Benjamin Elman, and Ku-Ming Kevin Chang, eds., World Philology (Cambridge, MA: Harvard University Press, 2015), 138.

3 Benjamin Elman, From Philosophy to Philology: Intellectual and Social Aspects of Change in Late Imperial China (Cambridge, MA: Harvard University Press, 1984), 212-221; Ori Sela, China's Philological Turn: Scholars, Textualism, and the Dao in the Eighteenth Century (New York: Columbia University Press, 2018); Benjamin Elman, "Early Modern or Late Imperial? The Crisis of Classical Philology in Eighteenth-Century China," in Sheldon Pollack, Benjamin Elman, and Ku-Ming Kevin Chang, eds., World Philology (Cambridge, MA: Harvard University Press, 2015), 225-244.

${ }^{4}$ Yang Xiong, Fangyan (Beijing: Guoji wenhua chuban gongsi, 1993) (Original first century BCE). An analysis of the work in English is Paul Serruys, The Chinese Dialects of Han Times According to Fang Yen (Berkeley: University of California Press, 1959). For commentaries, see Hua Xuecheng, Yang Xiong "Fangyan" xiaoshi lungao (A revised and annotated commentary of Yang Xiong's Fangyan) (Beijing: Gaodeng jiaoyu chubanshe, 2011). 
than a pictograph. It also emphasized how deeply semantics were tied to phonetics. Xu Shen indicated pronunciation by pairing a character with a homophonous counterpart, a method that would be replaced in later centuries by a more precise system of transcribing sound. The system, called fanqie (反切), indicated the pronunciation of one character by using a separate set of characters to denote its initial, final, and tone. As an example, the character奔, pronounced "bēn," would be indicated with the characters 榜 (băng) to indicate the initial b, and 跟 (gēn) to indicate both the final "ēn" and the high flat tone (ping 平 tone, most closely correlated to the first tone in Putonghua). ${ }^{5}$ While this method did not describe absolute pronunciation, it was effective in drawing phonetic relationships among and between characters, as well as separating each morpheme into smaller phonetic elements. It also relied upon a clear method for categorizing Chinese characters by their phonetic value, the groundwork of which was laid by scholars such as Xu Shen and Yang Xiong.

Later dynasties saw the emergence of dictionaries and rime tables, which offered more precise phonetic data than Han dynasty texts. ${ }^{6}$ The earliest of these sources for which we have evidence is the Qieyun (切韻, $601 \mathrm{CE}$ ), though it only exists in scattered records. The oldest complete rime dictionary still extant is the Guangyun (廣韻, $1008 \mathrm{CE}$ ), which recorded the phonological categorization of 26,000 characters. ${ }^{7}$ The dictionaries separated characters first according to tone, and then by their riming finals. ${ }^{8}$ Over the centuries, scholars continued to amend and add to these existing works. Sweeping rime categories became more specific as authors further separated rimes by place and manner of articulation, such as open mouth/closed mouth (kaikou/hekou 開口/合口), or "sound pronounced with the teeth meeting/sound pronounced at the tips of the teeth" (zhengchiyin/chitouyin 正齒音/齒頭音). ${ }^{9}$

The Qing was a turning point. Beginning in the seventeenth century, a fractious group of intellectuals began to challenge epistemological methods that had been made popular by mainstream Qing scholars who

${ }^{5}$ It is important to note that this was Bernhard Karlgren's analogy, and he was quite critical of fanqie. Gao Benhan (Bernhard Karlgren), Zhongguo yinyunxue de yanjiu, 4.

${ }^{6}$ David Prager Branner, "Introduction: What Are the Rime Tables and What Do They Mean?," in David Prager Branner, ed., The Chinese Rime Tables: Linguistic Philosophy and Historical-Comparative Phonology (Amsterdam: John Benjamins Publishing, 2006), 2.

${ }^{7}$ For a more complete explanation of how these texts influenced scholars in the Qing and Republican periods, see N. G. D. Malmqvist, Bernhard Karlgren: Portrait of a Scholar (Bethlehem, PA: Lehigh University Press, 2011), chapter 8.

8 These include pingsheng (平聲), shangsheng (上聲), qusheng (去聲), and rusheng (入聲).

${ }^{9}$ Branner, "Introduction," 7-11. There is a fair amount of debate about the dating of these dictionaries and tables. For a summary of these debates see Branner, "Introduction," 13-18. 
enjoyed government patronage. Calling their work kaozheng (考證) or "evidential scholarship," they contended that since the Song dynasty (960-1279), the true meaning of classical texts had been obscured by the hegemony of Neo-Confucian philosophy, its mysticism encouraging inattention to precision and disregard of evidence. This could be remedied, they argued, by returning the study of the Classics to philological analysis of the words in those texts. ${ }^{10}$

Among kaozheng scholars' numerous methods of uncovering hidden truths shrouded in text, one was diachronic studies of phonology. To understand how oral language changed over time, men such as Jiang Yong, Duan Yucai, and Dai Zhen used texts like the Shuowen jiezi and other dictionaries and rime charts as tools to analyze character phonologies with increasing detail, dividing Chinese morphemes into narrower groupings. ${ }^{11}$ Beyond this, interest in phonology in the Qing was not limited to one group of scholars. Rime tables served as the foundation for popular games, which, among other uses, likely taught phonology in early education. ${ }^{12}$ Imperially authorized books in the late eighteenth century used characters for their phonetic value to "spell" pronunciation, which, in the $1860 \mathrm{~s}$, were used to teach the Northern pronunciation to Manchu elites - an early precedent for the language reform of the following decades. ${ }^{13}$

In a word, phonological research in the High Qing was widely used, widely known, and far from rudimentary. As Benjamin Elman warns us, we ignore the sophistication of their scholarship "at our own peril." ${ }^{14}$ Yet this sophistication notwithstanding, their research was nonetheless framed by their worldview. Kaozheng scholarship aimed to create knowledge that buttressed the dynastic system, a system that politically and culturally organized their world. Their goal was consistently in service of understanding the past, not the present.

By the early nineteenth century, when kaozheng xiaoxue research had reached its height, an intellectual revolution was brewing in Europe. The promise of the nation-state violently upended the presumption that the only knowledge valuable to society was its elite historical canon. For this and many other reasons - including the disbanding of the Jesuit order and the arrival of Protestants in China interested in plebeian culture - the

${ }^{10}$ Elman, From Philosophy to Philology, 215-220.

${ }^{11}$ Elman, From Philosophy to Philology, 220-221.

12 Mårten Söderblom Saarela, “'Shooting Characters': A Phonological Game and Its Uses in Late Imperial China," Fournal of the American Oriental Society 138, no. 2 (April 2018), 327-359.

${ }^{13}$ Mårten Söderblom Saarela, "Alphabets Avant La Lettre: Phonographic Experiments in Late Imperial China," Twentieth-Century China 41, no. 3 (2016), 234-257.

${ }^{14}$ Elman, From Philosophy to Philology, 221. 
strides made in Chinese philology during the High Qing and the new directions of nineteenth-century Western Sinology developed largely independently. It was not until the early twentieth century that the intellectual trajectories of Western and Chinese scholars finally converged. Influenced by the nation-state framework, Chinese intellectual movements dismissively claimed that Qing scholars' research, with its focus on understanding elite antiquity, was irrelevant in a new China.

But these kaozheng methods hardly disappeared. Instead, despite their own rhetoric, twentieth-century Chinese scholars gazed upon these methods Janus-faced, discrediting kaozheng scholars' assumptions while actively relying upon the groundwork they built. Kaozheng research found new life in service of the nation-state in a way that had a particular bearing on the culture of fangyan. Their contention that Chinese phonology linked past to present was mobilized by twentieth-century scholars to prove certain fangyan had an empirically determined connection to antiquity. In this way, kaozheng methods were used to show which fangyan groups could claim cultural ownership over the imagined Chinese past - and which could not.

\section{Fangyan Literature before the Twentieth Century}

Rime tables and character compendiums supported a unique conceptualization of the relationship between sound and script in imperial China. Popular conceptualizations of oral and local languages before the nineteenth century were also formed and sustained through literature. Some of the earliest examples of vernacular vocabulary emerged in translations of Buddhist chant booklets at the beginning of the Tang dynasty $(617-907) .{ }^{15}$ The use of fangyan in these religious texts were rooted in common Buddhist practice; like Protestant missionaries several centuries later, Tang dynasty Buddhist clergy privileged the oral transmission of scriptures over the use of written texts. ${ }^{16}$ Such conventions encouraged a tradition of "faithfully preserv[ing] and replicat[ing] spoken language in written language" in the centuries before the modern period. ${ }^{17}$

${ }^{15}$ Liang Peizhi (Leung Pui-Chee), Xianggang Daxue suo cang muyu shu xulu yu yanjiu (Woodenfish books: Critical essays and an annotated catalogue based on the collections in the University of Hong Kong) (Hong Kong: Hong Kong University Press, 1978), 245-247.

16 According to Victor Mair, there was nothing inherent within the Buddhist canon that demanded the vernacular; it simply privileged oral, rather than written, teachings. Victor Mair, "Buddhism and the Rise of the Written Vernacular in East Asia: The Making of National Languages," Fournal of Asian Studies 53, no. 3 (1994), 707-751.

17 Though considered by scholars today as an example of early "vernacular" text due to the preponderance of polysyllabic words, fangyan-specific words are few. Without information about how individual fangyan were spoken centuries ago, it is difficult to pinpoint the localisms as belonging to a particular region. Don Snow, Cantonese as Written Language: 
The late-Ming dynasty (1368-1644) saw a broad expansion of printed materials for upper and lower classes alike. The period saw a proliferation of "woodenfish books," popular songbooks that included ditties such as "southern songs" (popular love ballads penned by elites), dragon boat songs (folksongs sung by the poorer masses), and woodenfish songs (long, often religiously inspired, narratives). ${ }^{18}$ These songs were often composed in the local vernaculars where they were sold. The provinces of Guangdong and Fujian, which held the lion's share of the publishing market, gained the power to both dominate the book market and set linguistic precedent. Books such as Zhao Ziyong's Cantonese Love Songs, printed in 1828, were widely circulated throughout the Qing dynasty, both within and outside Cantonese-speaking areas.

Another genre in which fangyan vocabulary and grammatical patterns were commonly used was opera. ${ }^{19}$ Kunqu (嵌曲), a style of opera popular near Hangzhou and Suzhou beginning in the late Ming, often weaved together phrases and vocabulary from Guanhua, classical texts, and local patois. ${ }^{20}$ In Kunqu scripts, Chinese characters were once again applied like rebuses: as stand-ins for phonetic pronunciation, and thus largely incomprehensible without using the oral language as a metric. Vernacular vocabulary, moreover, rarely accurately depicted local speech. They were used to exhibit stereotypes of regional cultures, thus serving more as a symbol of a particular characteristic than a transcription of common speech.

Fangyan thus served a variety of purposes in literature - as phonetic stand-ins, as the chosen language for popular non-elite literature, and as symbols of local stereotypes. But one commonality emerged from woodenfish booklets and opera scripts to dialogue in some of the most famous novels, such as Outlaws of the Marsh: they always denoted orality. This is

The Growth of a Written Chinese Vernacular (Hong Kong: Hong Kong University Press, 2004), 78.

${ }^{18}$ Snow, Cantonese as Written Language, 86-90; Glen Dudbridge, "The Goddess Huayue Sanniang and the Cantonese Ballad Chenxiang Taizi," in Books, Tales and Vernacular Culture: Selected Papers on China (Leiden: Brill, 2005), 309-320.

${ }^{19}$ What made these materials "fangyan" literature is somewhat debatable. In general, scholars have called these works "Cantonese" or "Wu dialect" literature because of the featured fangyan-specific characters or grammatical patterns. Yet we must be aware that the lines we draw between linguistic styles are quite fluid. In the case of opera scripts, for instance, vocabulary, sentences, and grammatical patterns were often weaved into texts that employed a wide variety of literary styles. Similarly, in woodenfish books, songs ranged from transcriptions of oral folk songs to literary poems; most were somewhere in between. Even the Cantonese opera, which took pride in its use of local dialects, would often employ different linguistic styles to emphasize various literary tropes.

${ }^{20}$ Zhang Han, "Vernacular Chronotope: The Philological Jiangnan in Late Imperial Chinese Drama," Paper presented at the annual meeting of the American Comparative Literature Association, Boston, MA, May 17-20, 2016. 
largely because fangyan were, and still are, considered solely oral languages. As Mair explains, "it remains almost unthinkable to write down any of the topolects [fangyan] in a relatively integral form." 21

Just as late-Qing scholars would question the very goals of kaozheng research while drawing upon its methods, they reimagined pre-twentieth century literature in similarly contradictory ways. As fin-de-siècle artists and scholars argued that the gap between oral and literary language needed to be eliminated, denouncing earlier literary forms for their decadence and obsolescence, they gazed with new eyes upon art forms with local vernacular language at their center such as opera, novels, and folksongs. For these reformers, the fact that fangyan carried the connotation of the oral made them an ideal vehicle for a language reform that sought the end of the distinction between script and speech altogether. In other words, in the process of exalting a literature that connoted fangyan as exclusively oral, these late-Qing reformers simultaneously made fangyan inspiration for a new written tradition.

In responding to Western prescriptions, late-Qing elites drank deeply from the history with which they were familiar. This section has attempted to introduce that history. Kaozheng methods of mobilizing phonologies to make sense of their cultural heritage, and pre-nineteenth century ways of rendering local language into written forms offered models for a new literature. Ultimately, what Western narratives did was highlight a problem - a problem that seemed very visceral to Qing elites after its military defeats. Understandings of oral and written languages, accumulated, debated, overturned, and exhumed from the Han dynasty through the Qing, provided a roadmap for solving them.

It is to those who proclaimed the problem in the first place that we now turn.

\section{From Hierolect to Dialect}

In 1703, George Psalmanazar, a native of Formosa (present-day Taiwan) wrote a detailed chronicle of the geography, history, customs, and language of his home. ${ }^{22}$ Published in London, he described for his English audience how the Formosan people tamed rhinoceroses for labor and beat snakes to extract their poison before consuming them as a food source. He recounted

${ }^{21}$ Mair, "Buddhism and the Rise of the Written Vernacular in East Asia," 725. I would add that, while Mair's contention is generally true, Cantonese speakers beginning in the early twentieth century have held, and still hold, that their fangyan can be written as a language distinct from Mandarin, as will be discussed in later chapters.

22 George Psalmanazar, An Historical and Geographical Description of Formosa, an Island Subject to the Emperor of fapan (London: s.n., 1704). 
Formosan funeral processions, wedding rites, and religious rituals, which he complemented with sketches of intricate gold plates with which the men adorned themselves. And he presented a detailed description of the Formosan language, including its phonetic alphabet and core vocabulary. The book took England by storm, selling out all copies within a year of its publication. Psalmanazar then took to the tour circuit, soon after which he was given a position at Oxford to translate biblical works into Formosan and begin work on his book's second edition. ${ }^{23}$

What was so remarkable about Psalmanazar's account was that it was pure fiction. A blonde haired, blue-eyed Frenchman, Psalmanazar had never traveled east of Germany. Yet while some suspected the veracity of Psalmanazar's account, none had the knowledge to discredit him. When he claimed that his complexion was pale because Formosan elites lived underground, or that the towering cities he described were erected using elephant labor, skeptics could not prove otherwise. Thus Psalmanazar went undetected for years, an expert of a society living only in his imagination.

The success of Psalmanazar's con rested upon his capitalization of Europe's cultural and intellectual landscape. He tapped into a fascination with the Far East that had begun pulsing through Europe at the turn of the eighteenth century. ${ }^{24}$ This enchantment was intricately tied to a religious conviction that humanity had a singular origin, and the associated belief that remnants of this shared antiquity could be found scattered across the globe. He also took advantage of gaps in popular knowledge. Europeans had hardly ventured beyond the coasts of Japan, China, Korea, or Taiwan, and could little attest to the lives of inland populations. ${ }^{25}$

But the most significant lacuna that Psalmanazar exploited was linguistic. Europeans in the eighteenth century, while having a strong grasp of Asian written traditions, knew little of languages spoken on the ground. Knowledge of Eastern empires was limited to the tales of a few select sojourners who translated and transmitted texts from abroad, shining a light on distant lands for audiences back at home. The nearly exclusive dissemination of classical texts produced an uneven focus on script over sound, and on ancient literary traditions over contemporary vernaculars. Cognizant of this disparity, Psalmanazar claimed that the Formosan

${ }^{23}$ Michael Keevak, The Pretended Asian: George Psalmanazar's Eighteenth-Century Formosan Hoax (Detroit, MI: Wayne State University Press, 2004), 6.

${ }^{24}$ This is a phenomenon Raymond Shwab called an "Oriental Renaissance." The Oriental Renaissance: Europe's Rediscovery of India and the East 1680-1880, trans. Gene PattersonBlack and Victor Reinking (New York: Columbia University Press, 1984).

${ }^{25}$ Keevak, The Pretended Asian, 6. 
language was "the same with that of Japan" but with a distinct pronunciation. ${ }^{26}$ In claiming that his invented language was essentially a dialect of a known language, Psalmanazar built his deception on a foundation of his audience's ignorance.

At the time Psalmanazar was touring Europe, most knowledge about Qing China came from Spanish and Italian Jesuits. ${ }^{27}$ These residents served as cultural arbiters; they presented Western science, religion, and art to the Qing court, and transmitted knowledge of the Middle Kingdom back home. ${ }^{28}$ Only permitted to reside in two or three select cities, all the while under the watchful eye of the Qing state, they saw little outside their provided compounds. ${ }^{29}$ Their writings reflected these strictures. They spilled ink on the intricacies of the Qing bureaucracy or novel inventions they witnessed, but could speak little on anything besides the texts and objects to which they were exposed. ${ }^{30}$

This was not to say that Jesuits in the Qing court knew nothing of local languages; Psalmanazar's well-spun deception proves that Europeans were aware of the existence of linguistic diversity within the countries of Asia themselves. But the depth and focus of that knowledge was restricted by both the authors' interests and the source material to which those authors had access. Any information they had on oral languages was guided by the classical scholarship to which Western sojourners had access and in which they expressed interest.

Such restrictions would not last. Over the following two centuries, epistemic shifts and political upheavals in Europe offered new imperfect metaphors through which these men could understand Asia, whereas imperial exploits changed the stakes for reimagining the region's significance. The Protestant Reformation marked the rise of the oral vernacular as the ideal vehicle for religious practice and literary style. The eighteenth-century emergence of comparative linguistics, driven in part by the expansion of linguistic knowledge through colonialism, buttressed the belief of humankind's commensurate road to progress. Finally, the spread of nationalism in the nineteenth

${ }^{26}$ Psalmanazar, An Historical and Geographical Description of Formosa, 266.

${ }^{27}$ For summaries of Matteo Ricci's life and work, see R. Po-chia Hsia, A fesuit in the Forbidden City: Matteo Ricci, 1552-1610 (New York: Oxford University Press, 2010); Mary Laven, Mission to China: Matteo Ricci and the Fesuit Encounter with the East (London: Faber and Faber, 2011).

${ }^{28}$ Benjamin Elman, On Their Own Terms: Chinese Science 1550-1900 (Cambridge, MA: Harvard University Press, 2005).

${ }^{29}$ The extent to which their movements were limited varied from emperor to emperor. Jesuits were perhaps the most constricted during the Qianlong period. See Liam Matthew Brockey, fourney to the East: The Fesuit Mission to China 1574-1724 (Cambridge, MA: Harvard University Press, 2009), 191-198.

${ }^{30}$ Fa-ti Fan, British Naturalists in Qing China: Science, Empire and Cultural Encounter (Cambridge, MA: Harvard University Press, 2004); Hsia, A Fesuit in the Forbidden City. 
century encouraged Europeans to see the roots of nation-states across the globe - and social Darwinism encouraged the placement of those nationstates into a global hierarchy. By the time Western settlers had gained access to the Qing through military fiat, these events in Europe had transformed into a coherent, if still ever-evolving, worldview. Sojourners in China placed their observations of everyday life in the Qing into an existing narrative, one informed by centuries of European history.

\section{Scribes of the Vernacular}

In 1839, British ships landed off the coast of Guangdong to fire the first shots of what would be a three-year war that irrevocably changed the course of history. The Qing, plagued by domestic decline, could hardly fend off the British navy - a powerful force fueled by the British Empire's increasing colonial resources. The humiliating defeat ended with a string of "unequal" treaties, granting Western countries unprecedented access to the empire's resources, land, and people.

The First Opium War was a watershed moment for one group in particular: the Anglophone Protestant. Evangelistic opportunities of which Jesuits could only dream soon became tangible for Protestants as they established churches and schools for the Qing's rural inland masses. To aid their proselyzation efforts, these missionaries and the societies that backed them directed resources toward language study, the publication of proselytization tracts, and the translation of the Bible and biblical texts.

Translation projects sparked a debate about linguistic style. The first Bible was translated into Chinese in 1807 and published in 1823 by Robert Morrison and William Milne, translated into what they called "High Wenli" (文理), or what we today might call classical Chinese. ${ }^{31}$ Both men were guided by the belief that only the elite classical tradition

31 Parts of the Bible had been rendered into Chinese before Morrison. Jesuit missionaries from France and Italy had translated parts of the scriptures in the seventeenth and eighteenth centuries, and the entire Bible was translated in 1821 by Joshua Marshman, but failed to gain support for publication before Morrison's. Morrison's was the first one to gain traction, and set a precedent for future translations. See Alexander Wylie, "The Bible in China," Chinese Recorder and Missionary fournal 1, no. 7-8 (1868), 121-129, 145-157; George Kam Wah Mak, "'Laissez-Faire' or Active Intervention? The Nature of the British and Foreign Bible Society's Patronage of the Translation of the Chinese Union Versions," Fournal of the Royal Asiatic Society of Great Britain and Ireland 20, no. 2 (2010), 167-190. It is also worth noting that, while Morrison claimed to have been writing in the High Classical, his version was roundly criticized for its "awkward prose." Patrick Haan, "The Bible as Chinese Literature: Medhurst, Wang Tao, and the Delegates' Version," Harvard Fournal of Asiatic Studies 63, no. 1 (Summer, 2003), 197-239. 
could serve as an appropriate vessel for sacred texts. Morrison professed a deep respect for the written classical language, deeming it the only language appropriate for the word of God. This language alone, he argued, "possesses something of the gravity and dignity of the ancient classical books," and was the sole language that was understood across geographic space, if not social class. ${ }^{32}$ Walter Henry Medhurst, another of these early translators whose versions were published in 1834, also proclaimed admiration for written Chinese and a generalized disdain for translation into "vulgar dialects." "There is perhaps no people who are more partial to reading than the Chinese, or who better appreciate beauty of composition and purity in style than their books." 33 But once Protestants moved beyond Guangzhou, missionaries in Fuzhou, Xiamen, and Ningbo found themselves in disagreement with Medhurst's dismissal of local patois, arguing that translations in High Wenli were inaccessible to their potential converts. As Reverend John Gibson, stationed in Swatow (present-day Shantou), proclaimed, "We cannot ... reach the millions of China by one version of the Scriptures. They must be translated into all the vernaculars before we shall be able to say that the people have the Word of God in their own tongue." 34

Missionaries' views on translation styles were undergirded by a host of commonly held assumptions about language in China. Their assumptions were based in part upon their own empirical observations - individual experiences they gathered, collected, and disseminated through periodicals and books. But these scattered observations became coherent narratives through the use of imperfect metaphors. Without what felt like a full picture of China before them, and emboldened by European notions that human history was commensurate around the world, missionaries filtered the fragmented information they collected through the lens of their own histories, making sense of what they saw by inserting it into streamlined narratives of historical progress modeled on the European experience. ${ }^{35}$

${ }^{32}$ Robert Morrison, Memoirs of the Life and Labours of Robert Morrison, comp. Elizabeth Morrison (London: Longman, Orme, Brown, Green and Longmans, 1839), 330.

${ }^{33}$ Walter Henry Medhurst, The Foreigner in Far Cathay (London: Edward and Stanton, 1872), 43.

${ }^{34}$ John C. Gibson, "Appendix: How Best Are the People of South China to Get the Word of God in Their Own Tongues?," in James Johnston, ed., Report of the Centenary Conference on the Protestant Missions of the World, Held in Exeter Hall (Fune 9th-19th), London, 1888, Vol. 2 (London: James Nisbit, 1888), 309.

35 The field of missionary linguistics in China is rich. See Edwin Pulleyblank, "European Studies on Chinese Phonology: The First Phase," in Ming Wilson and John Cayley, eds., Europe Studies China: Papers from an International Conference on the History of European Sinology (London: Han-Shan Tang Books, 1995), 339-367; van der Loon, "The Manila 
In particular, missionaries spoke of language in the Qing in reference to two disparate analogies. First, many Protestant missionaries saw classical Chinese as an ancient, religious language, one that "stood pre-eminent ... [occupying] the same position as Latin and Greek [did] among Europeans." ${ }^{36}$ Such an analogy stemmed from the history of Protestantism in Europe. In the sixteenth century, Martin Luther lambasted the excesses of the elite Catholic order and suggested that individual Christians bypass the priesthood to form a direct relationship with God. Given the paucity of Latin speakers in Germany and other areas of Europe during that time, God's ears were suddenly filled with prayers in the plethora of local vernaculars spoken in hamlets and villages across the continent. ${ }^{37}$ Thus the Protestant Reformation fundamentally revolutionized the very language through which the divine spoke: from a classical language to a vernacular one. Having seen no evidence of a comparable Chinese vernacular language movement, Protestants drew parallels between the nineteenth-century Qing and sixteenth-century Europe, awarding themselves the same starring role in both histories.

Others, however, were quick to argue that a written tradition used throughout the whole empire functioned like a national language -

Incunabula and Early Hokkien Studies," 1-43, 95-186; David Prager Branner, "Notes on the Beginnings of Systematic Dialect Description and Comparison in Chinese," Historiographia Linguistica International fournal for the History of the Language Sciences 24 (1997), 235-266; John DeFrancis, "A Missionary Contribution to Chinese Nationalism," Fournal of the North Asia Branch of the Royal Asiatic Society 83 (1948), 1-34; Chen Zhe, "Cong Dongfangxue dao Hanxue: Ai Yuese de bijiao yuyanxue yu Hanyu yanjiu" (From Eastern Studies to Chinese Studies: Joseph Edkins's comparative linguistics and Chinese language research), Guangdong shehui kexue Online Edition 4 (2011), n.p.; Zheng Mengjuan, "Zhongguo Yanfa: Xifang zaoqi zhongyao de wenyan yufa yanjiu zhuzuo" (Elements of Chinese Grammar (1814) by Joshua Marshman: An important monograph of Classical Chinese grammar during the early stage in the West), Shijie Hanyu jiaoxue Online Edition 3 (2009), n.p.; You Rujie, Xiyang chuanjiaoshi de Hanyu fangyanxue zhuzuo shumu kaoshu (A bibliography of works on Chinese dialectology by Western missionaries) (Harbin: Heilongjiang jiaoyu chubanshe, 2002); Guo Hong, "19 shiji zhongqi chuanjiaoshi yu Ningbo fangyan pinyin" (Mid-nineteenth-century missionaries and the phoneticization of Ningbo fangyan), in Tao Feiya, ed., Zongiiao yu lishi: Zhongguo Fidujiaoshi yanjiu (Religion and history: Research on Chinese Christianity) (Shanghai: Shanghai Daxue chubanshe, 2013), 130-144. This also extends to the study of missionary linguistics globally. For an excellent summary of scholarship so far, see the introduction to the first edited volume, Otto Zwartjes and Even Hovdhaugen, "Introduction," in Otto Zwartjes and Even Hovdhaugen, eds., Studies in the History of the Language Sciences, Volume 106: Missionary Linguistics/Lingüistica misionera: Selected Papers from the First International Conference on Missionary Linguistics, Oslo, 13-16 March 2003 (Philadelphia: John Benjamins Publishing, 2004); Otto Zwartjes, "The Historiography of Missionary Linguistics: Present State and Future Research Opportunities," Historiographia Linguistica 39, no. 2/3 (2012), 185-242.

${ }^{36}$ The China Mission Handbook, "Introduction," xviii.

${ }^{37}$ Elizabeth Einstein, The Printing Press as an Agent of Change (Cambridge: Cambridge University Press, 1980). 
the second European analogy that missionaries projected onto the linguistic landscape they observed. Since the eighteenth century, Europeans understood languages and nations as being "parallel." 38 Based on this, many missionaries claimed that the unity of its written tradition supported granting it a title derived from its place of origin: the "Chinese language." This was certainly Morrison's contention. For him, it was the only language that webbed China to all corners of its empire and all epochs of its history. Oral dialects, on the other hand, were "so widely numerous that persons of neighbouring provinces ... are frequently unable to carry on a conversation of any length without having recourse to writing." ${ }^{39}$ As European empires gave way to nation-states, a unified language was seen as integral to a nation's survival. ${ }^{40}$ European missionaries like Morrison thus assumed that language in China could, and should, inspire a similar historical consciousness. Since the Chinese were a "singular people with a singular history," the only unified option for a "Chinese language" was, in fact, the written classical. ${ }^{41}$

These two imperfect metaphors for a Chinese language shaped translation projects. Some missionaries accepted Morrison's metaphor of classical Chinese as the Chinese national language, and thus sought solely to edit and improve his 1823 biblical translation. Twelve delegates from Europe and the United States completed the so-called Delegates version of the Bible in 1852, with subsequent classical versions published in 1863 and $1890 .^{42}$ Yet the perceived elitism of the classical language inspired missionaries to search for alternatives. Some attempted to balance the contradiction between the unity and inaccessibility of classical by translating the Bible into "Easy Wenli." ${ }^{43}$ A categorization invented by missionaries which reflected the variety in literary styles they encountered, Easy Wenli emerged in the late $1870 \mathrm{~s}$ as a response to the perceived class barriers of High Wenli, imagined to be easily understood by those with minimal classical training. ${ }^{44}$ Still others believed that the most broadly comprehensible vernacular was

38 Thomas Trautmann, Languages and Nations: The Dravidian Proof in Colonial Madras (Berkeley: University of California Press, 2006), 1.

39 Morrison, Memoirs, 330, 500.

40 Richard Watts, Language Myths and the History of English (Oxford: Oxford University Press, 2011), 33.

41 The China Mission Handbook, 50.

42 I-Jen Loh, "Chinese Translations of the Bible," in Sin-wai Chan and David E. Pollard, eds., An Encyclopaedia of Translation: Chinese-English, English-Chinese (Hong Kong: Chinese University of Hong Kong Press, 1995), 55-59.

43 Loh, "Chinese Translations of the Bible," 59-61.

${ }^{4}$ It is important to note that the terms Wenli and Easy Wenli were both missionary terms. See Yuen Ren Chao, "The Languages and Dialects of China," Geographic Fournal 102, no. 2 (August, 1943), 66. 


\section{Bible Publications for 1894.}

\begin{tabular}{|c|c|c|c|c|c|c|}
\hline \multirow{2}{*}{\multicolumn{4}{|c|}{ Bibles. }} & \multirow{2}{*}{$\begin{array}{c}\text { Testaments. } \\
15,900\end{array}$} & \multirow{2}{*}{$\begin{array}{l}\text { Portions. } \\
539,000\end{array}$} & \multirow{2}{*}{$\begin{array}{l}\text { Total. } \\
554,900\end{array}$} \\
\hline & & & & & & \\
\hline Easy Wên-li & $\ldots$ & $\ldots$ & $\cdots$ & 5,100 & 191,600 & 196,700 \\
\hline Classical & & ... & 2,700 & \multirow{2}{*}{275} & 173,000 & 184,820 \\
\hline \multicolumn{2}{|c|}{$\left.\begin{array}{c}\text { Charaster Vernacular } \\
\text { other than Mandarin }\end{array}\right\}$} & $\cdots$ & 3,875 & & 42,450 & 46,600 \\
\hline \multirow{2}{*}{\multicolumn{2}{|c|}{ Romanized Vernacular }} & $\ldots$ & $\cdots$ & ... & 6,700 & 6,700 \\
\hline & & & 6,575 & 30,395 & 952,750 & 989,720 \\
\hline
\end{tabular}

Figure 1.1 Bible publications organized by language. Source: J. A. Silsby "The Spread of Vernacular Literature," Chinese Recorder and Missionary fournal 26 (November, 1895), 509.

Mandarin, which is why the Union Delegates sponsored that biblical translation in the first years of the twentieth century. ${ }^{45}$

Yet hundreds of thousands of variations abounded as missionaries individually embarked upon their own translation projects (Figure 1.1). In 1894, while the vast majority were in Mandarin, Easy Wenli, or classical, over 53,000 partial or full translations of biblical materials were in local vernaculars. ${ }^{46}$ This is largely because, while most major Biblical societies aimed toward breadth of use, individual missionaries believed that translation into dialect was the only way to truly fulfill the Protestant mission. In the words of Reverend C. Leaman, an American missionary in Nanjing:

Before the [Protestant] Reformation the local dialects, jargons, and effete modes of speech were probably as numerous ... and as widely different ... as those which are now fostered within all this Mandarin district. Yet Luther's province was to show them that what was pure and good in all these "German jargons from the rasping gutturals of the Swiss Rhine to the lisping sibilants of the half Slavic

45 Loh, "Chinese Translations of the Bible," 61-63.

46 J. A. Silsby, "The Spread of Vernacular Literature," Chinese Recorder and Missionary fournal 26 (November, 1895), 509. Also discussed in Federico Masini, The Formation of the Modern Chinese Lexicon and Its Evolution Toward a National Language: The Period from 1840 to 1898 (Berkeley: University of California Press, 1993), 36; Alexander Wylie, Memorials of Protestant Missionaries to the Chinese Giving a List of Their Publications and Obituary Notices of the Deceased (Shanghai: American Presbyterian Missionary Press, 1867), 326-331. 
Drina," could be gathered up and made a vehicle of accomplished verses upon every theme ... Now, in this have we not a prophecy of what the missionary is to do for China and her language? ${ }^{47}$

Like Europeans on the cusp of the Protestant Reformation once argued, the power of the vernacular lay as much in what it was - the language of the common people - as in what it was not - the ancient and stilted language of a higher class. When Leaman beseeched missionaries to follow the "prophecy" of what "the missionary was to do for China," he beseeched them to embrace the use of dialects in their teachings. As a statement from the Christian Vernacular Society of Shanghai tells us: "The importance of the Vernacular lies in the fact that the chief object of the Christian Church is to convey Christian truths. Now, these truths are entirely strange to the Chinese, whether highly or plainly educated in their own literature ... the putting of strange truths in a plain dress helps the understanding of them." 48

Among those who believed that dialects represented the true "vehicle" for the Protestant gospel, debates ensued about how best to render exclusively oral languages into written forms. Many claimed that, like the classical Chinese language, the characters themselves were elitist and outdated. Their criticisms portrayed characters as an indictment on the country's relative development: modern nations, in their view, had a phonetic script. Some advocated the replacement of the sinograph with the Roman alphabet, which they believed would make vernaculars more widely accessible to missionaries and their illiterate congregants alike. Yet advocates of Romanization, while quite vocal, were not the only missionaries who believed that a novel way of rendering vernaculars into text could remedy China's backwardness. Indeed, the diversity of their answers to what they perceived as China's plight is made plain by the variety of methods for translating the Bible that Protestants employed .

\section{Romanization}

"The usefulness of Romanization is becoming apparent as the number of Christians increases, and the minds of the Chinese (and shall we say missionaries?) are awakening to a keener realization of China's needs."49 So declared a letter to the editor in the Chinese Recorder and Missionary

47 C. Leaman, "A Missionary Tour Through the Province of Sze-Chu'en," Chinese Recorder and Missionary fournal 9 (March-April, 1878), 99.

48 Y. K. Yen, "The Shanghai Vernacular: Address of the Reverend Y. K. Yen at the Annual Meeting of the Christian Vernacular Society of Shanghai," Chinese Recorder and Missionary fournal 23 (August, 1892), 387.

49 Chinese Recorder and Missionary fournal, July, 1902, 358. 
Fournal in 1902. Though short, the letter laid bare the underlying ambitions behind romanization efforts in China at the twilight of the nineteenth century. ${ }^{50}$ Romanization was not simply a practical solution for translating Chinese dialects. Those who translated biblical works into roman orthographies did so out of a firm belief that they were solving a "need" that stemmed beyond language alone.

This sense that missionaries were destined to solve "needs" in the countries in which they proselytized had obvious colonial undertones. Around the world, romanization advocacy and colonialism went hand in hand. ${ }^{51}$ While missionaries in China did not have the same incentives as those in India or Kenya, in which a comprehensible script would aid Britain's economic conquests, their desire to both increase their own access to foreign lands and "save" residents from themselves bear similarities. ${ }^{52}$

In Qing China, traces of these global colonial linkages can be found in various missionaries' chosen orthographies, many of which have origins in British exploits into India and the Near East. ${ }^{53}$ Arguments presented in favor

${ }^{50}$ For a list of when the first version of various vernacular biblical texts first appeared in each region, see You, Xiyang chuanjiaoshi, 13-21. A list of works published before 1890 can also be found in Rev. S. F. Woodin, "Review of the Various Colloquial Versions and the Contemporary Advantages of Roman Letters and Chinese Characters," in Records of the General Conference of the Protestant Missionaries of China Held at Shanghai, May 7-20, 1890 (Shanghai: American Presbyterian Mission Press, 1890), 89; "Appendix B: Table of Colloquial Versions of Scriptures," in Records of the General Conference of the Protestant Missionaries of China Held at Shanghai, May 7-20, 1890 (Shanghai: American Presbyterian Mission Press, 1890), 706.

${ }^{51}$ Adrian Hastings, The Construction of Nationhood: Ethnicity, Religion and Nationalism (Cambridge: Cambridge University Press, 1997); Derek Peterson, "The Rhetoric of the Word: Bible Translation in Mau Mau and Colonial Kenya," in Brian Stanley, ed., Missions, Nationalism, and the End of Empire (Grand Rapids, MI: William B. Eerdmans, 2004), 165-182; Ross King, "Western Protestant Missionaries and the Origins of Korean Language Modernization," Fournal of International and Area Studies 11, no. 3 (2004), 7-38; R. S. Sugirtharajah, ed.,The Bible in the Third World: Pre-Colonial, Colonial, and Post-Colonial Encounters (London: Cambridge University Press, 2001).

52 Robert A. Yelle, The Language of Disenchantment: Protestant Literalism and Colonial Discourse in British India (Oxford: Oxford University Press, 2013), 85.

${ }^{53}$ Robert Morrison's 1815 Chinese-English dictionary, a compendium of Chinese characters organized alphabetically, used an orthography inspired by the "Manuscript Dictionaries of the Romish Church," or the Chinese-English dictionaries derived from the manuscripts and documents of Portuguese Catholic missionaries to China in the eighteenth century. Later descendants of the Morrison orthography tapped not into the Jesuit global network, but rather, the British Empire. "Church romanization," first popularized by William Medhurst in his dictionary of the Hokkien (present-day Fujian) dialect, added diacritic marks to Morrison's orthography to note tones, a system used in eighteenth-century Sanskrit studies. The influence from Sanskrit was all the more prominent given that Medhurst first learned the Hokkien dialect in Malacca, a central node on the British colonial network. Amended slightly to accommodate the eight tones of the Hokkien spoken language, this orthography, later known as Pèh-ōe-jī, was popular well 
of romanization similarly echo European colonial discourse calling them to "fix" non-European societies. First, romanization advocates often extolled the benefits of romanized script in promoting literacy. A prominent advocate of this position was John Gibson, an English Presbyterian missionary based in Swatow. ${ }^{54}$ Gibson wrote several treatises highlighting the ease and speed with which Chinese people became literate through exposure to romanized biblical material: roman letters were easier to use, easier to learn, and easier to write, therefore making the scriptures more accessible to a wide range of audiences. ${ }^{55}$ There was also the question of access - many of these missionaries touted the advantages of a romanized script in reaching nonliterate people, of whom the majority were women. ${ }^{56}$ While no exact statistics exist,

into the twentieth century in Taiwanese churches. Ann Heylen, "Missionary Linguistics of Taiwan. Romanizing Taiwanese: Codification and Standardization of Dictionaries in Southern Min (1837-1923)," in Ku Wei-ying and Koen de Ridder, eds., Authentic Chinese Christianity: Preludes to Its Development (Leuven: Leuven University Press, 2001), 144; Henning Klöter, The Language of the Sangleys: A Chinese Vernacular in Missionary Sources of the Seventeenth Century (Leiden: Brill, 2011), 47. Several other missionaries to China drew upon the "Asiatic orthography" created by eighteenthcentury British Calcutta circuit judge Sir William Jones. The Asiatic Orthography found patronage among missionaries in China with Elijah Bridgman's orthography of Cantonese in his Chinese Chrestomathy in the Canton Dialect. E. C. Bridgman, A Chinese Chrestomathy in the Canton Dialect (Macao: S. Wells Williams, 1841). It also inspired Samuel Wells Williams, first in his 1856 Tonic Dictionary and then two decades later in his Syllabic Dictionary of the Chinese Language. In the latter, he used the Asiatic Orthography to render eight different dialects into romanized script: Southern Mandarin, and the dialects of Beijing, Shanghai, Ningbo, Fuzhou, Swatow, Guangzhou, and Amoy. Samuel Wells Williams, A Tonic Dictionary of the Canton Dialect (Guangzhou: Office of the Chinese Repository, 1856); Williams, Syllabic Dictionary of the Chinese Language.

${ }^{54}$ In the early twentieth century, the teaching of phonetic scripts is well documented. As one example, in 1902, a letter to the editor by Ms. E. Black described her attempts to teach a classroom of twelve and thirteen year olds Roman script. Ms. E. Black, "Teaching Romanized Vernacular," Chinese Recorder and Missionary fournal 33 (February, 1902), 90-91. There is evidence that this was occurring earlier as well. In the same issue that Ms. Black crowed her accomplishments, notes from the editor describe a congregated effort to establish the successes and failures of teaching the romanized script. "Notes," Chinese Recorder and Missionary fournal 33 (February, 1902), 91. John Gibson, in his effort to encourage all missionaries to adopt a romanized script, recounts several examples. John Gibson, "Review of the Various Colloquial Versions and the Comparative Advantages of Roman Letters and Chinese Characters" in Records of the General Conference of the Protestant Missionaries of China Held at Shanghai, May 7-20, 1890 (Shanghai: American Presbyterian Mission Press, 1890), 88.

55 Gibson, "Review," 88.

${ }^{56}$ In 1888, Reverend Robert Stewart reported his desire to use romanized forms of Fuzhou dialect to give access to biblical material to women and children. This did not mean that women were solely taught the romanized script; descriptions of girls' schools in China mentioned instructions in characters. Miss Laura Haygood, "Essay: Girl's Schools," Records of the General Conference of the Protestant Missionaries of China Held at Shanghai, May 7-20, 1890 (Shanghai: American Presbyterian Mission Press, 1890), 227; C. M. Ricketts, "How to Reach the Women of China," Records of the General Conference of the Protestant Missionaries of China Held at Shanghai, May 7-20, 1890 (Shanghai: American Presbyterian Mission Press, 1890), 235. 
these efforts clearly shaped the culture of Protestant missionary work for decades. Nearly seventy years after Reverend Leaman wrote his defense of romanization, his daughter Mary, in reference to a looming decision concerning the reprinting of the phonetic Bible, proclaimed, "the phonetic script gave us the bible-reading church." 57

The belief that missionaries were spreading literacy and, by extension, modern citizenship extended outside the church. Several missions opened what were called local vernacular schools or missionary schools, which often opted to teach in roman characters. To the best of my knowledge, earliest reference to these schools was by August Hanspach, who founded several in Guangdong in 1863. In his report to the Berlin Society, he discussed how the children in his twelve schools learned several religious texts by heart. $\mathrm{He}$ described teachers who believed that teaching the romanized script was successful in reaching "even the poorest men and women." thus not only considered their ease of use - consumption by the local population was also taken into consideration (see Figures 1.2 and 1.3).

Ultimately, romanization proponents presumed that linguistic modernity was the foundation of the modern nation state. As missionary W. A. P. Martin proclaimed, "our alphabet is readiest gradus ad parmassun [steps to Parnassus], a stepping stone alike to Mandarin and to Wenli. Our alphabet will do for this Babel of dialects what steel braces do for deformed limbs."59 These missionaries, who were observing efforts in Germany, Italy, and France to turn "peasants into citizens" through language standardization, believed that the only way that China could achieve a similar standardization was through a phonetic script. Some even went as far as to argue that the script caged the country into a monarchical hierarchy, portraying the script itself as antithetical to a modern republican or democratic system. By limiting literacy to the educated elite - which, romanization advocates argued, occurred naturally with the complex Chinese script - the imperial government excluded the masses from public life.

It is important to recognize that romanization advocates were not necessarily representative. Yet their strong advocacy, and financial support from powerful institutions, allowed them to set the tone for debate.

57 This speech was found amongst a series of papers by Mary Leaman to Yuen Ren Chao, Y. R. Chao Papers, folder "Chinese National Language: National Phonetics," box 27, University of California Bancroft Library, Berkeley, California.

58 August Hanspach, Report for the Years 1863 and 1864 of the Chinese Vernacular Schools (Hong Kong: A. Shortrede, 1865), 7. The extent to which these schools affected the general population is unknown, but it is unlikely that the impact was widely felt. Hanspach places his numbers in 1863 as 260 pupils, a relatively negligible number for the city of Fuzhou, let alone the entire empire.

59 W. A. P. Martin, "A Plea for Romanization," Chinese Recorder and Missionary fournal 38 (September, 1907), 502. 


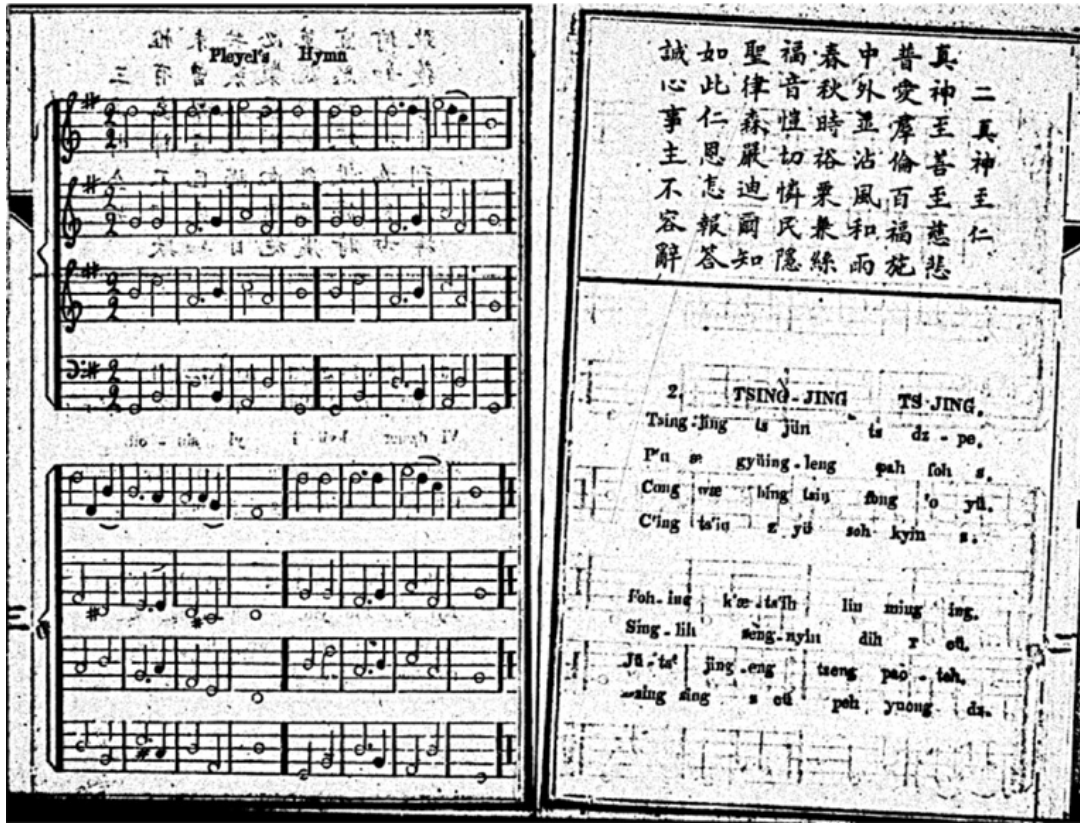

Figure 1.2 Hymnal in Ningbo dialect with romanized script and characters. Source: Edward Clemens Lord, Tsan shen yue chang (Hymns and tunes compiled by E. C. Lord, Ningbo) (1856).

Their belief that language was weakening the nation was posed as both practical observation and humanistic concern. As such, when other missionaries crafted their arguments against romanization, they did so on romanization advocates' terms. These opponents of romanization did not reject its supporters' central premise - that the way language was spoken and used in the Qing made it fundamentally unfit for the modern world.

\section{Other Orthographies}

T. P. Crawford, a proto-fundamentalist Southern Baptist who came of age in pre-Civil War Kentucky, found the use of the roman alphabet in China a fundamentally flawed concept. Crawford was one of the more controversial missionaries to develop a church in nineteenth-century China. Those who knew him describe him as stubborn and single-minded. Deeply conservative, 


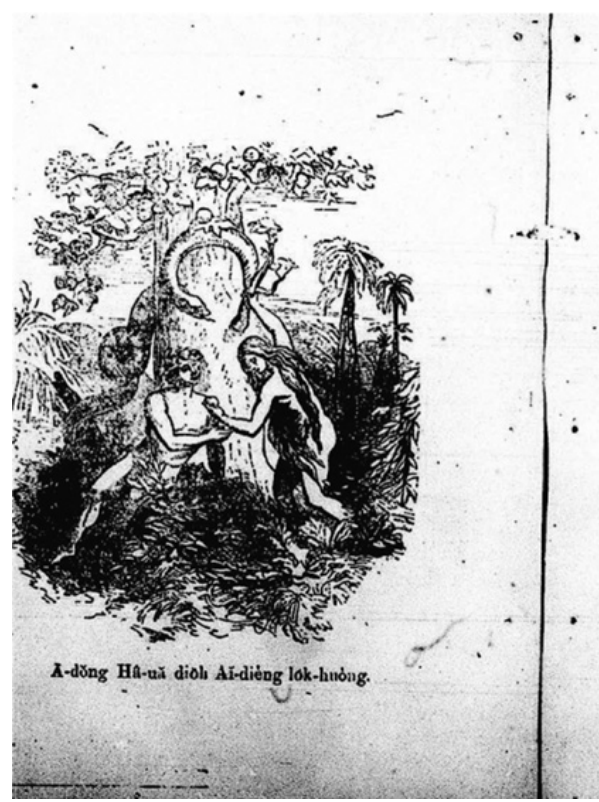

Dมิ 1 Dt:.

A-Dưng IHa-La Dioh Aí-Dièng L.žk-Hubug.

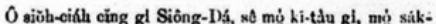

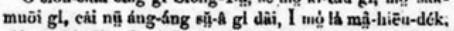

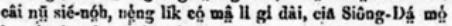

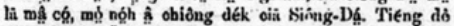

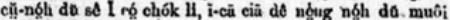

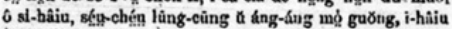

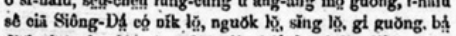

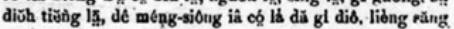

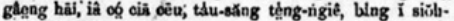
16i, sī̌h-loii.

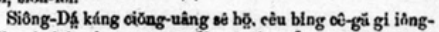

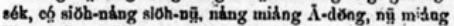

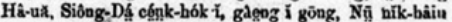

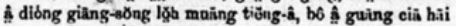

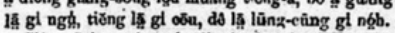

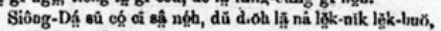

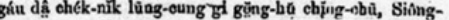

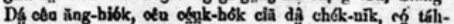

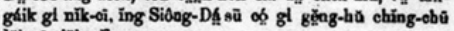
lob ei siob-nile.

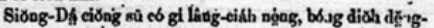

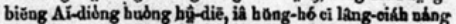

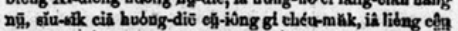

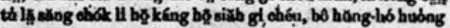
In ô nik-miling gl obeu, il $\Delta$ ois biek-ileng-ink of chíu,

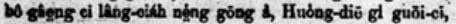

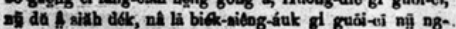

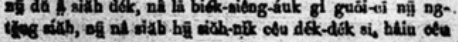

Figure 1.3 Book of Genesis in Fuzhou dialect. Source: Seng ging du siok kie mung (sheng jing tu shuo qi meng) (n.p., 1890).

he vehemently protested missionaries engaging in all non-evangelistic activities, which caused disputes with his wife when she created a general education school in Shandong. ${ }^{60}$

Yet as conservative as he was, his ideals about the Chinese language were rather radical. From his perspective, there was nothing in the Chinese language worthy of conservation. Chinese characters were beyond impractical; for Crawford, they represented Chinese racial inferiority. "Already China's ponderous works on military tactics, medicine, religion, philosophy and astronomy are obsolete, while her other heathen productions - the Confucian Classics not excepted, are hastening to that bourne from which hieroglyphics never return."61 Crawford found his colleagues' solution similarly unfitting; as English, French, and Spanish

${ }^{60}$ While Crawford protested his wife's activities, he himself engaged in plenty of nonreligious activities, from real estate ventures to Chinese language studies. Lovelace Savage Foster, Fifty Years in China: An Eventful Memoir of Tarleton Perry Crawford (Nashville: Bayless-Pullen, 1909).

${ }^{61}$ T. P. Crawford, "A System of Phonetic Symbols for Writing the Dialects of China," Chinese Recorder and Missionary fournal 19, no. 3 (March, 1888), 101. 
speakers each pronounced the script differently, the letters alone could not guarantee a singular pronunciation among different speakers. "English speakers pronounce the word "day" in six different ways, but they all write it with the same three letters." 62

As such, Crawford crafted his own phonetic script to serve in lieu of Chinese characters. ${ }^{63}$ Invented during his first winter in Shanghai in 1852, the system transcribed Chinese initials, finals, and tones in a series of interconnected strokes. Each initial and final was reflected with two to four horizontal strokes, connected together by one perpendicular stroke (see Figure 1.4) ${ }^{64}$ His character system, he claimed, accommodated China's linguistic realities. Mainly, they were intentionally phonetically flexible like Chinese characters, but were not born of the country's socalled backward history. With a little editing, Crawford explained, he could adopt his system to different dialects. "Phonography does not require a separate sign for every shade of articulation, but only for those which distinguish words according to the perceptions - not of foreigners, but of natives." 65

Crawford employed the same metaphors as romanization advocates but mobilized them to very different ends. Like Gibson and Leaman (see the previous section), he imagined China's history would follow the path that Europe and the United States had forged. But he did not see linguistic unification as a necessary stop on that path. "Neither Greek nor Latin became the medium of communication in modern Europe .... Only the dialects have life, and out of them must come future China." ${ }^{66}$ For Crawford, a "modern" language was both living and coupled with a phonetic script. Unification and roman letters were not necessary conditions.

Crawford's phonology, though limited in its dissemination, was well known by other missionaries, inspiring praise and imitation. ${ }^{67}$ Perhaps

${ }^{62}$ Crawford, "A System of Phonetic Symbols," 101-110. This complaint about roman characters was by no means new. Robert Morrison, "Introduction," Dictionary of the Chinese Language in Three Parts, Vol. 1, pt. 1 (London: Kingsbury, Parbury and Allen, 1823).

${ }^{63}$ Foster, Fifty Years in China, 67-69.

${ }^{64}$ Crawford, "A System of Phonetic Symbols," 101-102. For an analysis of how his system translated into Shanghainese, see Guo Hong, "Shanghai tuyinzi yufa' yu Gaodipi de fangyan pinyin tixi" ("The grammar of Shanghai vernacular characters" and Crawford's dialect phonetic system), in Tao Feiya, ed., Zongjiao yu lishi: Zhongguo fidujiaoshi yanjiu (Religion and history: Research on Chinese Christianity) (Shanghai: Shanghai Daxue chubanshe, 2013), 120-129.

${ }^{65}$ Crawford, "A System of Phonetic Symbols," 109.

${ }^{66}$ Crawford, "A System of Phonetic Symbols," 101-102.

${ }^{67}$ Rev. Harlan P. Beach, "Another Chinese Phonology," Chinese Recorder and Missionary fournal 19 (July, 1888), 293-298. 
PHONETIC SYMBOLS FOR CHINESE DIALECTS.

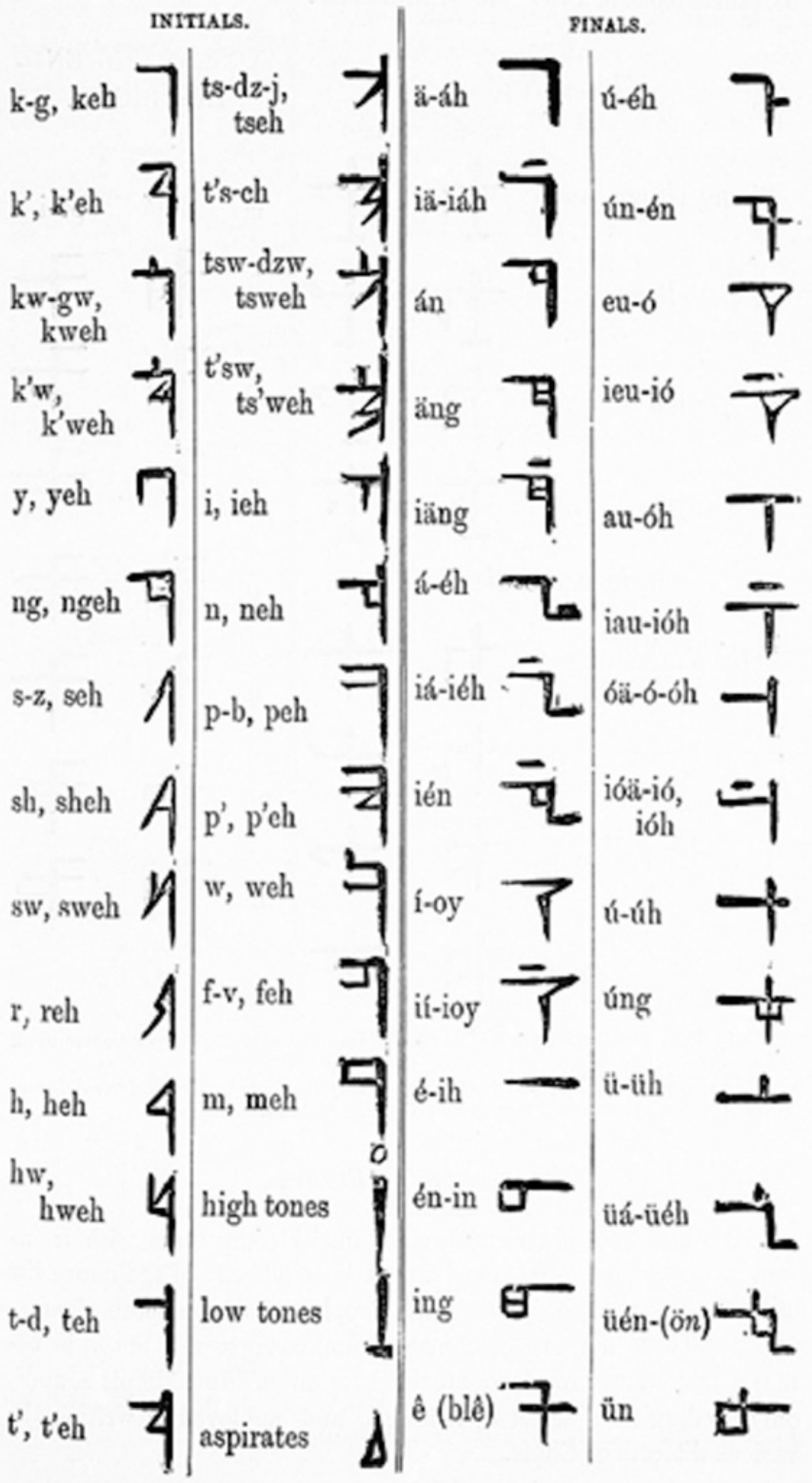

Figure 1.4 T. P. Crawford's phonetic symbols for Chinese dialects. Source: T. P. Crawford, "A System of Phonetic Symbols for Writing the Dialects of China," Chinese Recorder and Missionary Fournal 19, no. 3 (March, 1888), 103. 
this was in part because his solution to China's "backward" language was not to simply impose his own native script, but rather, construct something new for Chinese people to use; as a unique script that had no ties to foreign nations or cultures, missionaries like Crawford believed it would be more readily accepted by the Chinese as indigenous. As Crawford claimed, his renunciation of roman letters demonstrated a commitment to allow the "living dialects of the land" to flourish. ${ }^{68}$ This was Crawford's definition of linguistic modernity: a standardized phonetic script that promoted oral diversity.

\section{Vernacular in Characters}

On the other side of the spectrum were those missionaries who did not feel that China was destined to shed its so-called hieroglyphs to modernize its language. With our best estimates, character-based vernacular translations were far more common than romanized texts or those in other phonetic scripts. In 1894, Reverend Silsby estimated that nearly 50,000 of these publications, including the entire Bible, individual testaments, or individual books, were written in "character vernaculars other than Mandarin" (see Figure 1.1) ${ }^{69}$ In contrast, this number was just over 6,000 for romanized publications. ${ }^{70}$ Thus despite the campaigns by people such as John Gibson, or the creativity of people such as T. P. Crawford, missionaries overwhelmingly interpreted their duty to "put strange truths into plain dress" as using the native script.

There were also those who believed that characters were actually well suited to the country's linguistic landscape. A commentator in the Chinese Recorder and Missionary fournal, Reverend A. Sydenstricker, claimed that the host of pronunciations for one single character made the language incompatible with a phonetic script. Even in the same locale, he argued, pronunciations varied widely, not to mention the thousands of mutually unintelligible dialects outside the cities of Nanking or Beijing. Moreover, he argued, the script itself had adapted to its numerous homophones. $\mathrm{He}$ wrote, "It is a well-known fact to us all that a large number of characters have the same sounds. And this peculiarity would be immensely augmented if ... aspirates and tones were ignored." A romanized script "would be about as difficult to interpret as the enigmatical responses of the Delphic

${ }^{68}$ Crawford, "A System of Phonetic Symbols," 101.

${ }^{69}$ Silsby, "The Spread of Vernacular Literature," 509.

${ }^{70}$ While it must be noted that these numbers only include publications from the three main biblical societies - the National Bible Society of Scotland, the British and Foreign Bible Society, and the American Bible Society - they dominated the market. 
oracle. ${ }^{71}$ Others contended that pushing for romanization would do little to aid in mutual intelligibility, as there was no evidence that a romanized script would actually create uniformity. Sydenstricker again made an argument for characters - since characters of the same class followed the same phonetic rules (i.e., all characters pronounced $l i$ counted as one "class" of characters and therefore had identical pronunciations in other dialects), the characters actually aided learners studying multiple different vernaculars. ${ }^{72}$

Beyond this, opponents raised the possibility of "Chinese prejudice," or the fear that a foreign script would necessarily signify a foreign ideology. Protestants prided themselves on the universality of their faith, and to advertise the Bible's foreignness was to defy the very premise of their religion. Similarly, missionaries were actively aware of the dangers they faced as strangers in a strange land - their exotic foreign scripts drew unwanted attention to their oft-perceived as heretical religion. And finally, there were those who maintained that these debates over script were quite irrelevant to their assigned task. As Sydenstricker scoffed, "I fail to see how the question at hand has anything special to do with the work of evangelism.",73

Character proponents' opposition to romanization did not mean that they did not share concerns with romanization advocates. It was not that they considered the Chinese language sufficient as it was. Rather, they believed that the vernacular languages - the living, contemporary Chinese languages that defined local society - were best expressed with characters. For these missionaries, linguistic modernity simply meant a written language that reflected local vernaculars at the full extent of their authenticity. This required the native script.

\section{The Introduction of the Comparative Method}

In 1889, Thomas Watters, an Irish diplomat with a penchant for botany, wrote a summary of recent scholarship on the Chinese language:

Within the last fifty years ... the production of Manuals for learning Chinese, Grammars, Dictionaries, Translations of Chinese books and other works of miscellaneous character on the language and literature, by European scholars, has increased very quickly. Of those books, many have been compiled to meet practical wants ... But the Science of Language has lately taken up Chinese, and

${ }^{71}$ Rev. A. Sydenstricker, "Romanizing the Official Dialect," Chinese Recorder and Missionary fournal (January, 1888), 36-37.

${ }^{72}$ Rev. A. Sydenstricker, "Variations in the Spoken Language of Northern and Central China," Chinese Recorder and Missionary Fournal (March, 1887), 105.

${ }^{73}$ Sydenstricker, "Romanizing the Official Dialect," 38. 
men trained in that Science have tried to fix the place and worth of Chinese among the languages of the world. ${ }^{74}$

Watters summarized here the publication accomplishments of the Protestant missionaries described in the previous section. He also highlighted a contemporaneous intellectual pursuit: a linguistic genealogy of world languages that could include the languages of China. The search for a globally inclusive taxonomy inspired the "science of language" to "take up Chinese," delivering China hands the perfect opportunity to mobilize their expertise in the service of knowledge. ${ }^{75}$

At its heart, the global linguistic taxonomy alluded to in Watter's reference to the "Science of Language" represented a quest to unearth the origin of human language, a task energized by an Enlightenment desire to craft a universal path of human progress. ${ }^{76}$ For Enlightenment thinkers, the so-called East revealed central human truths: traces of monotheism that resided in ancient India, or philosophies of ideal governance exhibited by Confucianism. ${ }^{77}$ The pursuit of humanity's origins inspired an upheaval in how European intellectuals studied language. From the rubble was born an academic field that would constitute the backbone of the study of languages in the modern era: comparative linguistics.

This epistemic shift did not simply interest language curios. It quickly became weaponized for the purposes of gaining and wielding political power. Under the guise of discovery, Europeans supported their colonial endeavors through empirical research, which gave them the tools to subjugate not only populations but also their histories and identityexpressions. ${ }^{78}$ From the eighteenth century to the present, it is difficult to separate the construction of linguistic models from Western imperialism.

74 Thomas Watters, Essays on the Chinese Language (Shanghai: Presbyterian Mission Press, 1889), 3.

${ }^{75}$ Frederick J. Newmeyer, The Politics of Linguistics (Chicago: University of Chicago Press, 1986), chapter 1.

${ }^{76}$ Urs App, The Birth of Orientalism (Philadelphia: University of Pennsylvania Press, 2011).

${ }^{77}$ Shwab, The Oriental Renaissance; David Mungello, Curious Land: Fesuit Accommodation and the Origins of Sinology (Stuttgart: Franz Steiner Verlag, 1994); Hartman, "Ideograms and Hieroglyphs"; Bradley L. Herling, German Gita: Hermeneutics and Discipline in the German Reception of Indian Thought, 1778-1831 (New York: Routledge, 2006), 60.

78 Joseph Errington, "Colonial Linguistics," Annual Review of Anthropology 30 (2001), 19-39; Joseph Errington, Linguistics in a Colonial World: A Story of Language, Meaning and Power (Oxford: Blackwell Publishing, 2008); Lisa Lim and Umberto Ansaldo, Languages in Contact (Cambridge: Cambridge University Press, 2016); Bernhard Cohn, Colonialism and Its Forms of Knowledge: The British in India (Princeton, NJ: Princeton University Press, 1996); Siraj Ahmed, "Notes from Babel: Toward a Colonial History of Comparative Literature," Critical Inquiry 39, no. 2 (Winter, 2013), 296-326. 
The father of comparative linguistics is often said to be British Calcutta circuit judge and well-traveled linguistic savant Sir William Jones. ${ }^{79}$ Jones spent much of his career traveling the reaches of the British Empire, collecting texts and artifacts along the way. In his travels, he recorded and catalogued the languages he encountered Sanskrit, Persian, Greek, and Hebrew. Based upon his observations, Jones proposed that the comparative study of languages could reveal a common ancestral "protolanguage," today known as the IndoEuropean language family. ${ }^{80}$

Later generations of linguists, while accepting Jones's main premise, were inspired by an entirely new conceptual framework: evolutionary theory. This transition was exemplified by the work of German linguist August Schleicher, most well known for what is called the Stammbaum or "family tree" model. ${ }^{81} \mathrm{He}$ crafted complex linguistic taxonomies in which languages, like organisms, related to one another via a network of common roots and ancestors (see Figures $1.5 \mathrm{a}$ and $1.5 \mathrm{~b}$ ). The trunk of Schleicher's model was the Indo-Germanic primitive language (analogous to Jones's Indo-European language family), from which were born stock languages, languages, and finally, dialects. Dialects thus occupied the lowest order in the hierarchy, and like a species, depended upon its

${ }^{79}$ Many scholars have pointed out that he by no means invented the methodology; he simply popularized it. See, for instance, Lyle Campbell, "Why Sir William Jones Got It All Wrong, or Jones's Role in How to Establish Language Families," Anuario del Seminario de Filología Vasca 'Fulio de Urquijo' 45 (2006), 245-264. For biographies on Jones and his works, see Garland Cannon, The Life and Mind of Oriental fones: Sir William Fones, the Father of Modern Linguistics (Cambridge: Cambridge University Press, 2006); Garland Cannon and Kevin Brine, eds., Objects of Inquiry: The Life, Contributions and Influence of Sir William fones (New York: New York University Press, 1995). Jones's work is also heavily criticized by Edward Said, who calls him "Orientalist Jones." As he summarizes, "to rule and to learn, then to compare Orient with Occident: These were Jones's goals, which, with an irresistible impulse to codify and subdue the infinite variety of the Orient to 'a complete digest' of laws and figures, customs, and works, he is believed to have achieved." Edward Said, Orientalism (New York: Vintage Books, 1978), 78. For a broader discussion of Said's perspective on Sir William Jones, see Haruko Momma, "A Man on the Cusp: Sir William Jones's 'Philology' and 'Oriental Studies," Texas Studies in Literature and Language 41, no. 2 (Summer, 1999), 160-179.

80 This new global episteme that privileged the taxonomic organization of natural phenomena was accompanied by a new power dynamic in the construction of knowledge - one in which European colonists collected information of the non-Western world to buttress Eurocentric science and colonial power. Cohn, Colonialism and Its Forms of Knowledge. This was introduced in his famous "philologer" passage. See Sir William Jones, "On the Hindus," Asiatic Researches 1 (1788), 422-423. Other summaries of William Jones's proto-Indo-European language family can be found in W. P. Lehmann, ed., A Reader in Nineteenth-Century Historical Indo-European Linguistics (Bloomington: Indiana University Press, 1967); Holger Pedersen, Linguistic Science in the Nineteenth Century, trans. John W. Spargo (Bloomington: Indiana University Press, 1962).

${ }^{81}$ Allan Bomhard, Reconstructing Proto-Nostratic: Comparative Phonology, Morphology, and Vocabulary (Leiden: E. J. Brill, 2008). 


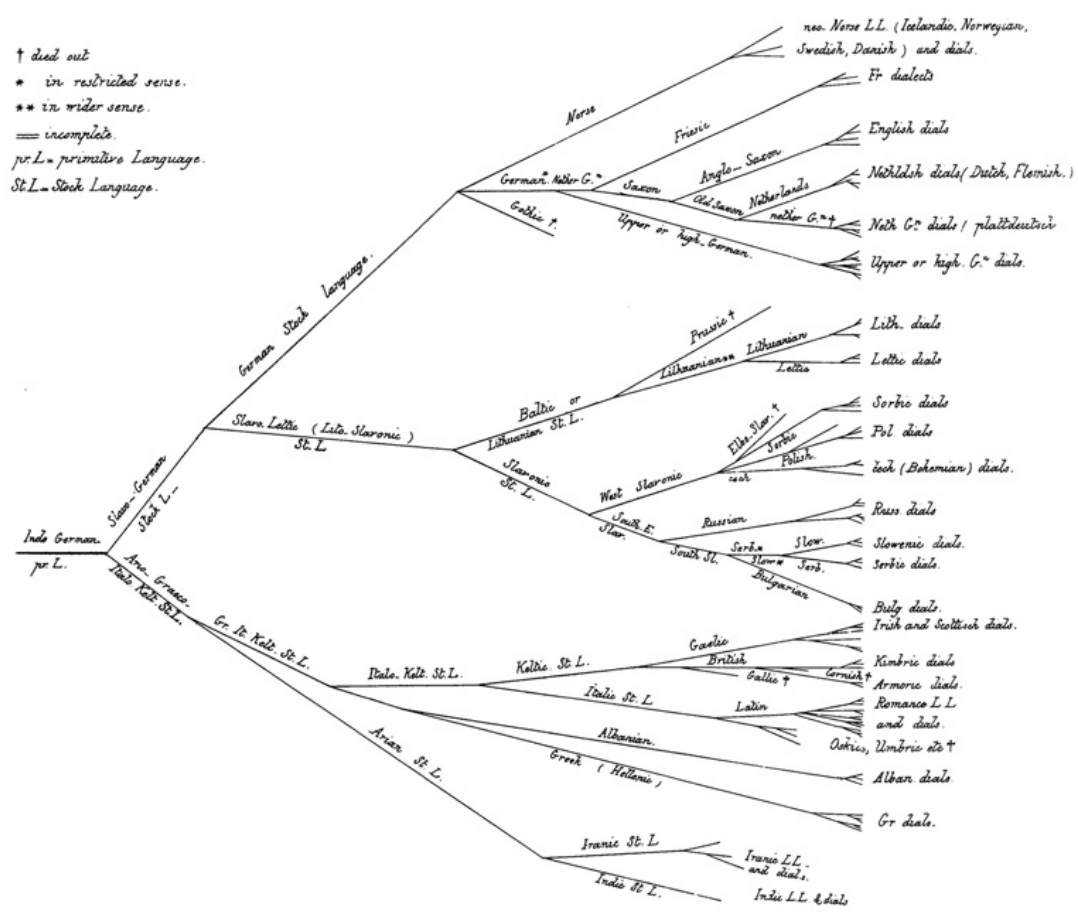

Figure 1.5a August Schleicher's Stammbaum model.

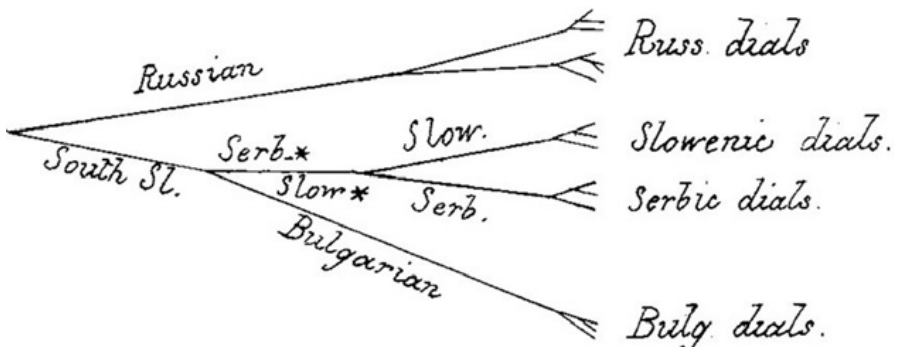

Figure 1.5b Detail of August Schleicher's Stammbaum model. Source: August Schleicher, Die Darwinsche Theorie und die Sprachwissenschaft (The Darwinian theory and the science of language), reprinted in August Schleicher, Linguistics and Evolution: Three Essays (Amsterdam: John Benjamins Publishing, 1983). Reprinted from their reprint with permission. 
genus for definition. Within this model, it became impossible to discuss the phonological properties of a dialect without understanding the language from whence it branched (see Figures 1.5a and 1.5b).

Schleicher's work, like that of Jones, reflects the epistemic frameworks of his time. As Schleicher presented his theories on evolutionary linguistic taxonomies on the European lecture circuit, his work was traveling across a global network of missionaries, diplomats, and scholars living abroad. In China, Schleicher's theories held sway over the influential generation of missionary language enthusiasts, who adapted their knowledge of China to fit into his comparative framework. Their application of Schleicher's model reinforced Europeans' preconceived notions about linguistic modernity in China and grounded their prescriptions on how they thought it could, and should, be achieved. ${ }^{82}$

\section{The Biblical Theorist}

Gloucester-born Joesph Edkins began his nearly sixty-year career as a Protestant missionary in China soon after the First Opium War. In addition to his evangelical work, he was a prolific writer, the editor of several periodicals, and the author of Chinese translations of key Western texts and textbooks on basic philosophy, natural science, geography, and logic. ${ }^{83}$ Yet while he was alive, it was his work on linguistics that garnered the most attention. He advocated the application of the theoretical framework of European linguistics - Schleicher's theory in particular - to Chinese languages, a belief crystalized in his 1871 manuscript China's Place in Philology: An Attempt to Show That the Languages of Europe and Asia Have a Common Origin. ${ }^{84}$ Edkins's primary thesis, grounded in his belief that the scripture "asserts the unity of the human race," was that the "Chinese language" shared a common ancestor to ancient Hebrew, Sanskrit, Mongolian, and Latin. ${ }^{85} \mathrm{He}$ proposed that ancient civilizations

${ }^{82}$ Errington, "Colonial Linguistics," 19-39; Errington, Linguistics in a Colonial World; Lim and Ansaldo, Languages in Contact; Cohn, Colonialism and Its Forms of Knowledge; Ahmed, "Notes from Babel," 296-326.

${ }^{83}$ Joseph Edkins, Xixue qimeng shiliu zhong (Sixteen Primers of Western Knowledge) (Shanghai: Tushu jicheng shuju, 1885). For more information on these translations, see Joachim Kurtz, The Discovery of Chinese Logic (Leiden: Brill Academic Publishing, 2011); Iwo Amelung, "Naming Physics: The Strife to Delineate a Field of Modern Science in Late Imperial China," in Michael Lackner and Natascha Vittinghoff, eds., Mapping Meanings: The Field of New Learning in Late Qing China (Leiden: Brill Academic Publishing, 1999), 381-418.

${ }^{84}$ Joseph Edkins, China's Place in Philology: An Attempt to Show That the Languages of Europe and Asia Have a Common Origin (London: Trübner, 1871).

85 Edkins, China's Place in Philology, 3; Joseph Edkins, "Chinese Philology," China Review 1 , no. 3 (1872), 181-190, and 1, no. 5 (1872), 293-300. 
originating in Babylon traveled across Eurasia to China, Mongolia, Japan, and Korea. Once groups settled into the space that would house their civilizations, they developed into separate ethnicities. Chinese people, Edkins claimed, presumably came across the Himalayas quite early, around 3000 BCE, as evidenced by their philosophical and civilizational similarities with ancient Egypt and ancient Babylon. ${ }^{86}$

The mainstay of his thesis was based on Schleicher's theory of "sound laws." 87 Schleicher's Stammbaum model assumed that human phonology developed upon a commensurate path, beginning with simple sounds that evolve into more and more complex sound systems, running parallel to the evolution of the human mouth. ${ }^{88}$ Edkins took this one step further, arguing that since "sound laws" dictated that "the history of one language is the history of any other," the reconstruction of one language's roots over time would illuminate the development of all languages. ${ }^{89}$ Speech began with labial sounds, which Edkins deemed the easiest to pronounce. Next came nasals, and then voiced and unvoiced aspirants. The last stage was the harmony of sound and script, namely, a written tradition that reflected colloquial patterns. Put simply, Edkins assumed language evolved from simplicity to complexity.

According to Edkins's interpretation of the sound law theory, the roots of all languages, ancient and contemporary, were monosyllables. "As in matter there are indestructible atoms, so in language there are indestructible roots," which were naturally smaller and more compact than the multisyllabic words we speak today. ${ }^{90}$ Logically speaking, therefore, monosyllabic languages best embodied the original human language. Chinese, Edkins argued, was still measurably monosyllabic, which indicated that the origin of human language could be most closely detected in

${ }^{86}$ Joseph Edkins, "Babylonian Influence on China," China Review 16, no. 6 (1888), 371. For a discussion on Sino-Babylonianism in China, see Tze-ki Hon, "From a Hierarchy in Time to a Hierarchy in Space: The Meanings of Sino-Babylonianism in Early Twentieth-Century China," Modern China 36, no. 2 (March, 2010), 139-169.

87 While Edkins certainly drew upon Schleicher, he most often cited Schleicher's successor, Francis Bopp. Edkins, China's Place in Philology, 6.

${ }^{88}$ E. F. K. Koerner, "Toward a Historiography of Linguistics: 19th and 20th Century Paradigms," in Toward a Historiography of Linguistics: Selected Essays (Amsterdam: John Benjamins Publishing, 1978), 33. Henry M. Hoenigswald, "On the History of the Comparative Method," Anthropological Linguistics 5, no. 1 (January, 1963), 6; John P. Maher, "More on the History of the Comparative Method: The Tradition of Darwinism in August Schleicher's Work," Anthropological Linguistics 8, no. 3, pt. 2 (1966), 1-12.

89 Joseph Edkins, Evolution of the Chinese Language, as Exemplifying the Origin and Growth of Human Speech (London: Trübner, 1888), vii.

90 Joseph Edkins, "The Roots of Chinese and All Other Languages," China Review 22, no. 6 (1897), 776. 
Chinese. ${ }^{91}$ This was the reason Edkins championed research on Chinese languages. Chinese could not only help enrich reconstructions of the Indo-European protolanguage; it was the key to unlocking humanity's linguistic past.

Edkins often used the term "Chinese" as a singular entity. It was not that he was unaware of China's oral diversity; as an expert in Cantonese dialects, he wrote extensively on China's myriad vernaculars in other venues. Rather, Edkins thought of the "Chinese language" not as the written tradition, but the phonology of ancient Chinese. ${ }^{92} \mathrm{He}$ maintained that during the Han dynasty, dialects in the north and west merged with the "old middle dialect" of Suzhou and Shanghai, which evolved into Southern Mandarin. This singular language, emerging in the Tang dynasty and recorded in ancient rhyming dictionaries, was for Edkins the only language that could serve as "Chinese." 93 For him, since language was of a higher taxonomic order than dialect, the Chinese language could not simply be chosen from among its vernaculars: it had to be a link that connected them all. Edkins's solution, therefore, was to assume that China's first recorded ancient phonology preceded its dialects, and could therefore logically be the ancestor to the dialects that existed in Edkins's time. He shifted the definition of language from a mode of communication used throughout a unified territory to a phonological system that embodied the genealogical link between all of China's vernaculars.

Though Edkins's efforts were praised, his conclusions were summarily dismissed. Many had trouble following his logic, and others rejected his equivalence of monosyllabic with primitive. Dr. O. Franke, for instance, criticized Edkins's methodological sloppiness. Franke admonished Edkins for claiming to closely follow Europe's comparative linguists such as Schleicher while running slipshod over the parameters they outlined. ${ }^{94}$ Watters accused Edkins of neglecting deductive reasoning, arguing that he engaged in an impossible task, assumed the conclusion, and found data

${ }^{91}$ Joseph Edkins, "Monosyllabism as Presented in Chinese," China Review 24, no. 6 (1900), 274.

92 There are times where Edkins uses the word "language" to refer to what he believed to be a unified language in ancient China, which subsequently broke into dialects during the Song dynasty (he called this the "Age of Dialects"). See Joseph Edkins, "The Age of Chinese Dialects," China Review 16, no. 5 (1888), 304.

${ }_{93}$ Edkins, China's Place in Philology, 36-37.

${ }^{94}$ Dr. O. Franke, "China and Comparative Philology," China Review 20, no. 5 (1894), 310-312. It is rather ironic since, as Thomas Trautmann notes, comparative linguistics was inextricable from the religious task of tracing the origin of man. Trautmann, Languages and Nations, 13-21. 
that supported his logic. "Our author sets out with a theory and collects facts or quasi-facts to agree with and prove his theory." 95

Franke's and Watters's criticisms marked an important turning point in the history of Chinese studies in Europe and the United States: the introduction of Sinology as a professional discipline. While earlier students of Chinese philology, such as Robert Morrison or Joseph Edkins, took up these studies as avocation, soon there was a crop of China hands that turned to academic study of China as vocation. ${ }^{96}$ Importantly, many of these first professional Sinologists began not as missionaries but as consular officers, whose goals and experiences were decidedly dissimilar from the missionaries preceding them. Edkins had come to China in the 1850s, when few Westerners had ever set foot inland. He established churches in villages to which other missionaries had not traveled, founded schools, and wrote textbooks for illiterate children, and bore personal witness to the governance of the Taiping Heavenly Kingdom. ${ }^{97}$ Men like Watters, however, were diplomatic representatives of their home countries. They had the benefit of learning languages through their country's consular service, often remained in China's major cities, and had little interest in engaging with the masses.

It is impossible to know the extent to which Edkins's vocation or personal beliefs impacted his research. But it is clear that many consular officers saw Edkins's submission to biblical claims just cause to dismiss him. Watters excoriated Edkins for assuming that all languages had a single origin due to his "religious convictions," accusing him of bringing in the "bugbear of the Bible as the ultimate authority on the subject of the origin and diffusion of language." ${ }^{98}$ In case his disdain was not clear, he stressed, "one had thought that it was now generally acknowledged that the Bible does not teach any science." 99

Today, Edkins is remembered for his authorship of a Chinese textbook collection. His work on language has been largely forgotten. Yet his

95 Watters found this cherry picking a common problem among other Chinese philologists, lamenting that they "take the languages as they find them, and indulge in the sport of picking out similarities of words 'en masse,' never minding the modern origin or the local obscurity of a sound." Thomas Watters, "China and Comparative Philology," China Review 20, no. 5 (1893), 319.

96 The most famous example of this was Herbert Giles, diplomat-turned-academic and cocreator of the Wade-Giles system of romanization.

${ }^{97}$ Edkins's narrative of his visit to the "rebel capital" can be found Joseph Edkins, "Narrative of a Visit to Nanking," in Jane R. Edkins, Chinese Scenes and People: With Notices of Christian Missions and Missionary Life in a Series of Letters from Various Parts of China (London: J. Nisbit, 1863), 239-307.

98 Thomas Watters, "China's Place in Philology: A Review of Mr. Edkins Last Work," China Review 1, no. 1 (1872), 55.

${ }^{99}$ Watters, "China's Place in Philology," 55. 
arduous defense of modern linguistic theory calls attention to how European frameworks shaped early Sinology. Even his critics had to admit, "it is more natural to suppose that the language or languages of China is or are lineally connected to other so-called stocks than to suppose that the contrary is the case. ${ }^{100}$ Edkins set a precedent for including Chinese dialects in a global linguistic framework. More importantly, Edkins's work inspired new directions in Chinese linguistic research. Emboldened by the major flaws in Edkins's work, scholars came to question his single-minded attempt to find the origin of language, seeking instead to study contemporary languages as they existed in the present. This new path would be forged by Edward Parker.

\section{The Dialectologist}

Edward Parker first entered China in 1869 as a young consular student of twenty years. A broad man with piercing blue eyes, he was curious, cheeky, and meticulous. ${ }^{101} \mathrm{~A}$ man with a knack for languages, he was perhaps best known for his scathing wit, on full display in his multiyear brawl with Herbert Giles over his characterizations of Chinese languages in his Chinese-English Dictionary. ${ }^{102}$ His writing style was graceless but informative, indicative of a man who had more passion for the discovery of things than for the art of presentation.

Yet Parker ought to be remembered for more than his brashness. During his time in China, he embarked on an ambitious retinue of linguistic research, much of which was quite radical for its time. A postmortem denouncement from distinguished Swedish linguist Bernhard Karlgren invalidated Parker's contributions in the eyes of his contemporaries, but Parker's work - both its unique contributions and its insight into the time in which he lived - is worth taking seriously.

One of the ways Parker's research diverged sharply from his colleagues was his belief that contemporary phonology should be the sole focus of linguistic research. He criticized attempts to retroactively reconstruct extinct phonologies as pure speculation, scoffing "it is impossible to conclude that there ever existed such alleged ancient sounds." ${ }^{103}$ But more importantly, Parker also believed this retroactive reconstruction

${ }^{100}$ E. H. Parker, "The Chinese Language," Chinese Recorder and Missionary fournal 15 (May, 1884), 151.

${ }^{101}$ Edward Werner, "Obituary Notice for Prof. E. H. Parker," Fournal of the North China Branch of the Royal Asiatic Society 57 (1926), ii.

${ }^{102}$ For a summary of battles with Herbert Giles, see David Prager Branner, "The Linguistic Ideas of Edward Harper Parker," Fournal of the American Oriental Society 119, no. 1 (1999), 13-14.

${ }^{103}$ E. H. Parker, "Reply to Dr. Edkins," China Review 21, no. 4 (1895), 276. 
was far less useful than the study of contemporary languages. For him, the entire purpose of learning a language was to communicate, which in China required facility in its dialects. "What is the object of the Englishman in learning to speak French? It is not to scramble through a number of sentences, regardless of genders, numbers and cases ... but to speak the language as nearly as possible as do the natives of France themselves." 104

Moreover, if scholars wished to create a linguistic taxonomy, the best way to approach it, Parker contended, was to start with local, living languages. ${ }^{105}$ His reasoning was rooted in the inexactitude of script. If scholars used written sources as a metric to gauge how people spoke in the past, they had to assume that script was a transparent and unchanging representation of sound. If this was a rather specious premise for alphabetic scripts, the nonphonetic nature of Chinese characters and the diversity of dialect phonologies made ancient Chinese all the more opaque. He wrote,

It will not do to take supposed foreign sounds, and attempt thereby to erect a standard, for we can never be certain what those foreign sounds were 2,000 years ago. Nor can we be sure whether the sound thus recorded was recorded in standard or local Chinese .... We cannot be even approximately sure how the ancient Greeks and Romans pronounced their languages; how much less, then, the Chinese? ${ }^{106}$

Ultimately, because of the inherent ambiguities of script, the passage of time, and the sheer variety of transcription methods, Parker concluded that any approximation of ancient sounds was impossible.

Thus for Parker, it was highly implausible that Edkins's "Chinese language," the phonology represented by Tang dynasty written sources, could be grafted onto the branches of Schleicher's tree. Yet if no extant or extinct language could scientifically serve as a genus to the dialects' species, then how could Schleicher's model be applied? Parker explained:

The essential principle, inherent in all Chinese dialects ... is that each Chinese word is a single independent unchangeable root, having a power $x$, or a shifting potentiality which cannot be ultimately expressed in letters. Though this power varies ... it remains constant as an abstraction, from which each variant may draw inspiration. Like the planets, all Chinese words have a fixed relation, but none have a fixed spot. ${ }^{107}$

${ }^{104}$ E. H. Parker, "The Comparative Study of Chinese Dialects," Fournal of the North China Branch of the Royal Asiatic Society 12 (1878), 23.

105 Parker, "The Comparative Study of Chinese Dialects," 26.

${ }^{106}$ E. H. Parker, "Philological Essay," in Herbert Giles, Chinese-English Dictionary (London: B. Quaritch, 1892), xviii.

107 Parker, "Philological Essay," xviii. 
Parker's Chinese language was $x$, an "abstraction," conceptual rather than material. Whether Parker believed such an abstraction ever existed, or if he imagined that it was and always will be conceptual is left ambiguous. But such considerations are beside the point. What was important was that, for Parker, the Chinese language first and foremost had to fulfill scientific constraints - namely, it had to epitomize the root of all of China's dialects. Moreover, if each dialect was a "planet" following a particular pattern of movement, then the only way to understand this pattern, the enigmatic $x$, was to collect and organize dialect phonological data. In a sense, he knew not what the Chinese language was, but he knew where to find it.

And find it he tried. He spent much of his life surveying dialects around the country. Though his methodology and data are largely lost to us today, his few publications expose his unique approach to Chinese linguistics. ${ }^{108}$ Parker outlined several dialect phonological charts, preceded by in-depth explanations of how various sounds differed from other dialects he surveyed. ${ }^{109}$ His most unique contribution was his study on "characterless words." In 1880, Parker published in the China Review a four-page list of dialect-specific words in the Beijing, Hankou, Fuzhou, Guangzhou, and Hakka dialects to which there were no character corollaries. ${ }^{110}$ Numbering no more than a few dozen, his list of words included onomatopoeic words such as "cough," plebian action words such as "to dig up" or "to flop down," and localized versions of everyday phenomena such as "bride" or "cicada."

These rather small studies were in keeping with his own "real point of interest": a comparison of the characterless words among dialects. ${ }^{111}$ This made Parker far ahead of his time - to question in a scientific capacity the sanctity of written sources was essentially inconceivable. Yet this study was revolutionary in other ways. Parker never claimed that Chinese dialects were not connected to some root. What his emphasis on non-character words implied, however, was that the language that connected dialects was not the written tradition. The essence of Chinese, its abstract value of $x$, could only be unearthed through oral speech.

${ }^{108}$ His data are buried in a scattering of phonologies published in the China Review, as well as Herbert Giles's Chinese-English Dictionary. The data in Giles's dictionary, however, are limited in their reliability, given the fact that Parker himself accosted Giles for how Giles used his own notes.

${ }^{109}$ For his phonologies, see E. H. Parker, "The Dialect of Eastern Sz-Ch'uan," China Review 11, no. 2 (1882), 112-121; E. H. Parker, "The Dialect of Wenchow," China Review 12, no. 5 (1884), 377-390; E. H. Parker, "The Dialect of Yangchow," China Review 12, no. 1 (1883), 9-18; E. H. Parker, "Canton Syllabary," China Review 8 (1880), 363-382.

110 E. H. Parker, "Characterless Chinese Words," China Review 9, no.2 (1880), 85-88.

111 Parker, "The Comparative Study of Chinese Dialects," 28. 
To the best of my knowledge, there is little evidence that Parker's ideas were commonly known among Chinese scholars. But Parker suggested something that would prove rather profound. The idea that a language did not have to be commonly spoken to be meaningful, that invented amalgamations could better capture the spirit of a people than extant speech, would find new life among Chinese reformers who, like Parker, believed that the true Chinese language was "an abstraction." As we will see in the next chapters, many in the twentieth century contended that invented languages could serve roles that languages currently spoken on the ground could not. Just as nation builders would work to reinvent China's past to fit its present needs, so, too, did men like Parker and a handful of twentieth-century Chinese language reformers believe that an ancient, idealized past could be reconstructed to serve as a contemporary national representative. Parker presaged the expansion of what language could be.

\section{Conclusion}

In 1961, Berkeley Professor of Linguistics Yuen Ren Chao (趙元任) wrote a short article titled, "What Is Correct Chinese?"112 It was a paradoxical question for Chao to ask: a central part of his long career was as a member of the language unification committee that defined and standardized national languages in China in the 1920s and 1930s. Yet rather than discuss the language that he himself had a hand in crafting, Chao instead flipped the question on its head and wrote of the language he spoke as a child in the 1890s, a time before there was such thing as a "standard Chinese." There was a script used largely by elites, he explained. There were archetypes for grammar, vocabulary, and syntax modeled on texts written hundreds of years before. Rhyming dictionaries approximated shared phonological principles by grouping characters together based upon phonetic characteristics. But these commonalities could hardly be called a standard.

Chao recognized the irony. He began his essay with a rather tongue-incheek, "To err is human, to correct is worse," intimating that his definition of "correct" defied expectations. But since he had been asked the question, he answered it by challenging his audience to reconsider what defined the language of a place, a culture, or a nation. Was it what most people spoke? Was it the historical traditions that defined and constrained it? Was it what the government claimed it was?

112 Yuen Ren Chao, "What Is Correct Chinese?” Fournal of the American Oriental Society 81, no. 3 (September, 1961), 171-177. 
The esteemed intellectual that he was, Chao's narration of how elites conceived of language in the final decades of the Qing was insightful, serving to dissuade his audience that the "Chinese language" of 1961 had timelessly existed. But what goes unmentioned was the extent to which the moment he pointed to, the moment he was born, was a watershed moment for the very question whose answers he sought. The language of his childhood was one in flux, as late-Qing scholars were imagining new ways to conceptualize not only their language, but the entire basis of their collective identity. As they did so, the frameworks they absorbed from their high-Qing predecessors, Western observers, and by the $1890 \mathrm{~s}$, Japan, forced them to reconsider the role of fangyan in its construction.

This chapter has focused on the historical threads that led to that moment of crisis. It established how fangyan before the nineteenth century were primarily used as local vernaculars and representatives of oral speech. It outlined how phonetics were treated as tools to uncover the wisdom of ancient texts. And finally, it introduced new observers, with power gleaned through imperialism, who wrote new histories and defined new roles for oral languages in the context of a swiftly changing modern world. In the late Qing, these narratives - a long tradition, built and reinvented over generations, and a new world order that made many of the assumptions undergirding that tradition seem inadequate converged.

As such, the story in this chapter is a modern one. ${ }^{113}$ Its purpose is to establish how these crisscrossed narratives inspired a diverse group of late-Qing patriots who began imagining China after empire. They imbued these earlier traditions with new meanings, combining them together in diverse ways: as prescriptions for policy, as valid intellectual frameworks, as artistic inspiration, and as traces of shared ethnicity, culture, and identity. These men, to whom we now turn, would initiate the dialectical process of creating a new vision of what it meant to be Chinese.

113 Sheldon Pollack so poignantly claims about South Asia that "Language was never an 'indispensable pole of identification' . . . before modernity made it such." While I would argue no such sweeping claims for China, it is worth noting how modernity shifted the relationship between language and identity. Sheldon Pollack, The Language of Gods in the World of Men: Sanskrit, Culture and Power in Premodern India (Berkeley: University of California Press, 2006), 511. 